DEPARTMENT OF THE INTERIOR

U.S. GEOLOGICAL SURVEY

\title{
REVIEW OF GEOTECHNICAL ASPECTS OF THE JORDANELLE DAMSITE, HEBER, UTAH
}

\author{
B y \\ U.S. Geological Survey \\ Open-File Report 91-398
}

Prepared at the request of the Utah Congressional Delegation

This report is preliminary and has not been reviewed for conformity with U.S. Geological Survey editorial standards and stratigraphic nomenclature

U.S. Geological Survey

Reston, Virginia 


\section{EXECUTIVE SUMMARY}

Jordanelle Dam is currenty being constructed on the Provo River near the town of Heber, Utah, by the U.S. Bureau of Reclamation (USBR). The construction project has been the focus of criticism from a variety of individuals and groups. Much of the criticism has been directed toward the long-term integrity of the embankment and appurtenances. In late March of 1991, the Utah Congressional Delegation asked the U.S. Geological Survey (USGS) to conduct an independent review of the geology and geotechnics of the Jordanelle damsite with specific reference to the adequacy of the USBR's investigation and conclusions. The scope of our investigation was thus limited to earth science issues. We did not attempt to develop any new inform-ation, except that we conducted two site visits, and different members of the review panel examined aerial photographs, maps, and exposed geologic features at the damsite. This report summarizes our findings.

The USGS review panel (hereafter referred to as the Panel) had access to all pertinent documents of the USBR including internal reports and reports of their consultants. We received recent geologic maps of the foundation and abutments, former and current planning documents, and several reports by former independent consulting groups; a list of documents reviewed is included with our report. Members of the Panel accom-panied the current independent Engineering and Architect's Consulting Group (Ralph Peck, Walter Arabasz, and Douglas Campbell; hereafter referred to as the Consulting Group) on a site visit in August and were able to question them about certain aspects of the dam's construction and site characteristics, as well as hear them discuss current safety issues. The Panel had the cooperation of the USBR, both from personnel at the Provo Construction Office and at the Engineering and Research Center in Denver. The Panel solicited comments from a number of recent opponents of construction of the Jordanelle Dam and were provided copies of corres-pondence and unpublished information relating to perceived safety problems at Jordanelle.

Following a preliminary review of the information, the Panel developed a list of questions that seemed to embody the principal safety concerns of all parties. The questions and responses follow. Technical findings, on which our responses are based, are presented in the body of this report. 
Are there major active faults beneath or adjacent to Jordanelle Dam that might rupture to the surface and threaten the integrity of the dam?

The nearest major fault, the Cottonwood fault, is shown on published geologic maps as an east-trending reverse fault that displaces Tertiary and older rocks directly west of the damsite. Despite suggestions that the Cottonwood is an active fault that extends across the damsite, we find no definitive evidence that the fault is either young or crosses the damsite as a coherent recognizable geologic structure. The major displacement on the Cottonwood fault clearly predates intrusion of the Oligocene (26-38 million years old) andesite porphyry that makes up most of the dam's foundation.

Characterizations of the Cottonwood fault as an "active fault" are not supported by the scientific data acquired during the several years of research that have focused on this specific question, or by information supplied by opponents of the dam. No stratigraphic evidence indicative of young (Holocene or late Pleist-ocene) fault movement-specifically, geomorphic expression of faulting, faulted surficial deposits, or a stratigraphic record of faulting - were found on faults in the foundation or abutments of Jordanelle Dam, or in numerous exposures adjacent to the west abutment. We agree with the USBR's conclusion that movement on faults in the west abutment occurred before the late Pleistocene ( $>130,000$ years ago), and probably is much older than that. In addition, the possibility of hidden traces of an active fault beneath flood-plain deposits of the Provo River seems remote.

Quaternary movement has been documented on the 2-mi- (3-km-) long Bald Mountain fault, but this fault is unlikely to cause surface displacement. Evidence that this fault has been active before the late Pleistocene $(>130,000$ years ago) is found in only one of three trenches. If movement were to occur on the Bald Mountain fault, rupturing would probably be confined to the postulated trace of the fault, well upslope and northwest of the west abutment.

Although several faults in the valleys of the Wasatch Range produced surface offset during the Quater-nary, they pose no surface-rupturing threat to the dam but could produce seismic shaking at the damsite. The nearest suspected active faults are those in Round Valley, $12 \mathrm{mi}(20 \mathrm{~km})$ south of Jordanelle have produced surface ruptures in the past 130,000 years. In addition, the Wasatch fault zone has produced earthquakes as close as $19 \mathrm{mi}(30 \mathrm{~km})$ from the damsite. 
Are there hidden geologic structures (faults) that may control the buried channel of the Provo

\section{River?}

The USBR studies revealed a sediment-filled channel of the Provo River that lies beneath the damsite. The hypothesis that the position of this channel is controlled by a north-south-trending fault is without scientific merit. Exposed and cleaned bedrock surfaces display structural continuity, thus proving that the postulated fault does not exist.

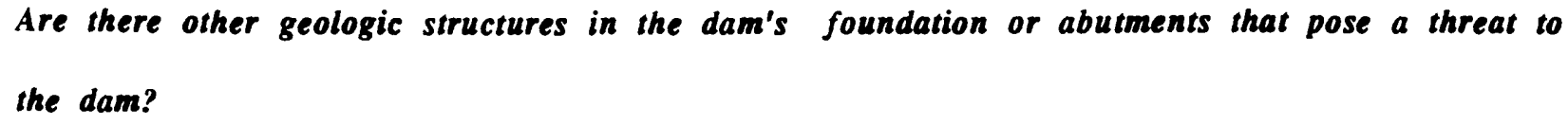

There is strong evidence that the andesite porphyry was intruded across the Cottonwood fault in Oligocene time (26-38 million years ago). After solidification, there was renewed faulting, possibly including renewed movement on the Cottonwood fault. The andesite porphyry along the projection of the Cottonwood fault was cut by many faults, thus forming a complex intersecting mosaic pattern. These post-intrusive faults are conspicuously discontinuous as revealed by detailed mapping and closely spaced drill holes. These faults served as channelways for migration of hydrothermal fluids during the episode of igneous activity in the Oligocene. However, the absence of a well developed shear fabric in these altered rocks suggests little, if any, displacement on most of the faults since Oligocene time. On the basis of the well documented discon-tinuous nature of the post-intrusive faults and indirect evidence that the faults are old (Oligocene), the Panel concludes that no faults with major young displacements can be projected through the foundation of the dam.

Exceptions to the predominantly Oligocene faulting are found in the west abutment where steeply and gently dipping faults with generally north-northwest strikes show evidence of post-alteration displacement. These faults are also discontinuous within the area of the abutment. They are currently being mapped by the USBR. Although the timing of movement on these faults cannot be constrained any closer than Oligocene or younger from evidence noted in the exposures of the foundation rock, none of them appear to be associated with faulting at the surface as shown by trenching and pre-excavation USBR aerial photography. The Panel does not consider these faults to be a seismic threat to the dam because there is no direct evidence that they are continuous with major faults that have been active recently. 


\section{Are there landslides that could compromise the integrity of the dam?}

There is no evidence of recent (Holocene) landsliding in the foundation of Jordanelle Dam, and there is no substantive evidence to indicate potential for landsliding that would damage the dam. Rocks that lie above low-angle slip surfaces in the north side of the west abutment will be almost entirely buttressed by the embankment, thereby preventing any possibility of failure into the reservoir.

Although minor landslide activity along the shoreline of Jordanelle Reservoir is to be expected during reservoir filling and during post-filling fluctuations of reservoir level, there is no indication that any of the slides will be large enough or of high-enough velocity to form waves that could overtop or damage the dam.

Continued landslide activity downstream from the dam could result from periods of heavy precipitation in the future. The only structure related to the Jordanelle damsite in this area is the emergency spillway. Because the spillway is covered, it is not likely to be damaged by shallow landslides. If damaged by deeper landslides, it could be repaired without affecting the integrity of the dam itself.

Do the quality, alteration, or permeability of rock in the dam's foundation present a concern for construction of a safe dam?

From an engineering standpoint, bedrock in the dam's foundation has not been significantly weakened by faulting, nor by hydrothermal alteration. The clayey alteration products resulting from the Oligocene-age hydrothermal alteration have tended to make former hydrothermal channelways less permeable than the unaitered rock. Except for localized and seemingly random zones of joint intersections and concentrations of joints, the small amounts of grout pumped into holes that penetrate the foundation at least $100 \mathrm{ft}(33 \mathrm{~m})$ support the general perception that the foundation rock has a low permeability or seepage rate. This charac-teristic is confirmed by the extremely low seepage rates observed in the deep part of the excavation into the buried river channel. If any throughgoing flow channels still exist, access to them by impounded waters will be effectively reduced by the grout curtains, blankets, and keels. 


\section{Has the Bureau of Reclamation adequately estimated the earthquake potential at the damsite and used appropriate earthquake design criteria?}

USBR seismotectonic investigations suggest three different scenarios for earthquakes that may affect the Jordanelle damsite. Although these earthquakes are unlikely (they have inferred repeat times of 2,000 to more than 50,000 years), the USBR used a conservative approach in their design, which allows the occurrence of these earthquakes during the life-span of the dam. A conservative approach is appropriate for a structure such as a dam whose failure may have serious consequences. Seismotectonic data obtained since 1988 do not alter USBR estimates of the maximum credible earthquake that could affect the damsite.

The USBR used two of the design earthquakes to represent the earthquake potential of the damsite, a magnitude 7.5 earthquake on the Wasatch fault $19 \mathrm{mi}(30) \mathrm{km}$ distant and a magnitude 6.0-6.5 earthquake in the immediate vicinity of the damsite. We consider magnitude 6.5 appropriate for the local earthquake and magnitude 7.5 appropriate for the Wastach fault. To represent the ground motion from these design earth-quakes, the USBR used three records of simulated motions. The first two records were intended to represent a local magnitude 6.5 and the third to represent a magnitude 7.5 on the Wasatch fault at a distance of $19 \mathrm{mi}(30 \mathrm{~km})$. The Panel is not entirely satisfied with the second record, but we believe that the first and third records taken together provide an appropriate basis for design. The USBR used these records to calculate the effects of the two earthquakes on the dam.

Evaluation of the calculations is a matter of engineering judgment that the Panel is not prepared to undertake, but we note the the calculations, based on assumed strength values that the USBR considers conservative, indicate that the dam design is safe.

Evaluation of the earthquake safety of the dam must include consideration of the potential of earthquakes of magnitude up to 6.5 that are induced by the impoundment of water in the reservoir. The ground-shaking hazard from such earthquakes does not need special consideration because there is no reason to expect that the shaking would exceed that represented by the design ground-motion records described above. However, an argument can be made that fault rupture in an induced earthquake might exceed the 6-in $(15-\mathrm{cm})$ upper limit given by the USBR. The most recent Consulting Group has assured us that the dam, as designed, can safely accommodate rupture displacements as large as 20 in $(50 \mathrm{~cm})$, which, in our opinion, are as large as need be considered. 


\section{CONCLUSIONS}

The U.S. Geological Survey Panel has found no safety concerns relating to geologic or seismologic issues that remain to be resolved at the Jordanelle damsite. The near-complete exposure of the foundation rock, an effort which is unprecedented for a damsite such as Jordanelle, has provided an excellent base for the USBR comprehensive and detailed mapping of the foundation exposures and has allowed them to integrate extensive subsurface drill-hole data with surface geology. We have reviewed the USBR investigations at the Jordanelle damsite with reference to perported hazards from active fauling, leaky and crumbly foundation rock, land-sliding, embankment failure due to ground shaking from earthquakes, and induced seismicity - each of which are important considerations in the design and construction of a critical facility. The Panel is satisfied that the USBR has fully demonstrated that these issues do not constitute a bonafide threat to the dam. 


\section{BACKGROUND INFORMATION}

The Bureau of Reclamation (USBR) is currently (September 1991) constructing a large earth-fill dam on the upper reaches of the Provo River, near Heber, Utah. This dam is named for the small community of Jordanelle, which was located at a narrow section of the valley about $6 \mathrm{mi}(10 \mathrm{~km})$ upstream (north) of Heber. According to recent USBR literature, the Jordanelle Dam will rise about $300 \mathrm{ft}(93 \mathrm{~m})$ above the valley floor and span a width of about $3,700 \mathrm{ft}(1,130 \mathrm{~m})$ at its crest. Its accompanying reservoir will maintain an active pool of about 320,000 acre-feet $(25,900 \mathrm{ha}-\mathrm{m})$ of water that is part of the USBR's Central Utah Project. In recent years opposition to the construction of Jordanelle Dam and Reservoir has come from local citizens and from a small group of scientists.

\section{REVIEW PROCESS}

The Utah Congressional Delegation requested that the U.S. Geological Survey (USGS) conduct an independent review of the USBR's Jordanelle damsite during the summer of 1991. The primary charge to our review panel (hereafter referred to as the Panel) was to determine whether or not the USBR has adequately addressed safety issues relative to the geologic and seismologic setting of the Jordanelle damsite. Although the Utah Congressional Delegation request mentioned concerns of dam design and structural engineering, these matters are beyond the expertise of the USGS and were not addressed. A companion panel of hydrol-ogists from the Water Resources Division of the USGS is addressing several water issues. The following describes the review process and the Panel's timetable for significant aspects of the review.

I. Definition Phase (May 1991)

- Visited the USBR's Provo Office to identify pertinent reports, studies, and background material, and interviewed USBR management to become familiar with the project.

- Identified significant issues requiring technical review, defined review process, and identified expertise required for Panel.

- Panel briefly reviewed previous work, documents, and perceived safety issues. Prepared USGS statement on scope and timing of review. 
- Personnel from the Office of Earthquakes, Volcances and Engineering (OEVE) and Geologic Division presented review plan to representatives of Department of Interior and Utah Congressional Delegation in Washington, D.C. Requested and received approval for review.

II. Review Phase (June to mid-August 1991)

- Panel members made a 2-day visit to the Jordanelle damsite on June 20-21, 1991. We conducted interviews with USBR personnel and other scientists in Provo, Utah, on June 20, 1991.

- Panel members reviewed pertinent documents and notes from interviews. Studied outstanding technical issues and reviewed pertinent scientific documents. Another site visit was made with USBR personnel and their Consulting Group (August 7, 1991).

III. Report Phase (mid-August to mid-September 1991)

- Panel members prepared individual technical reports, which were combined in this report through a series of meetings. A draft of the report was circulated among members of the Panel and a technical review of the second draft of the report was performed by non-panel members of OEVE.

- Prepared final draft of administrative report was transmitted to USGS management for review and presentation to Department of Interior and Utah Congressional Delegation representatives.

The panel had access to all pertinent documents of the USBR, including maps of the foundation and abutments, planning documents, and reports of USBR consultants and their Consulting Groups. In addition, we accompanied USBR's current Consulting Group (Walter Arabasz, Douglas Campbell, and Ralph Peck) on a site visit in August and were able to question them about details of the dam's construction and site characteristics and to discuss current issues; we also questioned them about their concerns. We had the cooperation of the USBR personnel at the Provo Construction office and at the Engineering and Research Center in Denver, Colorado. In the process of reviewing the USBR documents, we heard comments from a number of recent opponents of the Jordanelle Dam. Leon Hansen provided copies of former correspondence and unpublished information from years of mining activities in the surrounding area; he also made an informal presentation to us in Provo. In addition, we solicited the comments of Eric Christiansen and Morris Peterson (geology professors from Brigham Young University, Provo, Utah) who had expressed their concerns about the damsite in 1990. Eric Christiansen and Morris Peterson were interviewed in Provo, and Christiansen attended the Jordanelle damsite review in June 1991 
In July-August 1991, we had further contact with Leon Hansen through a series of facsimile transmissions (faxes). In addition, we solicited comments from a the following individuals who had been involved in studies at the Jordanelle damsit: Tim Sullivan (Department of Energy, Las Vegas, Nevada), Jim Peterson (law student, University of Colorado at Boulder, Colorado), Alan Nelson (U.S. Geological Survey, Denver, Colorado), and Dennis Williams (Department of Energy, Las Vegas, Nevada). In addition, we sought further information from USBR personnel (Frank McLean, Dean Ostenaa, Perry Hemsley, Chris Wood, and John Wilson) at the Engineering and Research Center, Denver, Colorado

\section{PANEL MEMBERS}

The U.S. Geological Survey assigned the following personnel to perform the independent review. Each of these persons is a senior scientist with from 15 to almost 40 years of career experience in his field of technical expertise. The Panel was comprised of Michael N. Machette (Panel Chairman), R. Emest Anderson, William B. Joyner, Robern L. Schuster, and Henri S. Swolfs.

\section{GEOTECHNICAL ISSUES}

The Geologic Division of the U.S. Geological Survey agreed to review a number of geotechnical issues that have been recently (1986-91) identified concerning the USBR's Jordanelle Dam near Heber, Utah (see following table). These concerns have been raised by opponents of the dam in a series of review meetings, damsite visits, and media reports. Additional concerns about water issues are being addressed by a second team in the Water Resources Division of the U.S. Geological Survey. The following table lists geotechnical issues that were identified in our initial assessment (May 1991); this table provides the general organization for the following technical discussions. 
GEOTECHNICAL ISSUE

(and strategy for review)
OPPONENTS'

VIEW
PROPONENTS'

VIEW

\begin{tabular}{|c|c|c|}
\hline $\begin{array}{l}\text { Active faults in area of } \\
\text { abutment } \\
\text { (Structural and Quaternary } \\
\text { geologists should review damsite } \\
\text { geology and reports.) }\end{array}$ & $\begin{array}{l}\text { Believe that an active fault (the } \\
\text { Cottonwood) passes through the } \\
\text { damsite. Believe that movement on } \\
\text { this fault could cause catastrophic } \\
\text { failure of the dam. }\end{array}$ & $\begin{array}{l}\text { Believe that no active faults are } \\
\text { present and that faults and shear } \\
\text { zones in exposed foundation rock are } \\
\text { old and are related to emplacement of } \\
\text { Tertiary intrusive rocks. }\end{array}$ \\
\hline $\begin{array}{l}\text { Geologic structures that } \\
\text { may control buried } \\
\text { channel of Provo River } \\
\text { (Must rely on USBR mapping } \\
\text { and drilling, and on inspection } \\
\text { by consultants. Review by } \\
\text { structural geologist.) }\end{array}$ & $\begin{array}{l}\text { A buried channel in the Provo River } \\
\text { flood plain could be controlled by } \\
\text { north-south trending fault. }\end{array}$ & $\begin{array}{l}\text { The sediment-filled channel is } \\
\text { fluvial (caused by erosion) rather than } \\
\text { strucurral (caused by faulting) based } \\
\text { on drilling, geophysics, and exposure } \\
\text { of the "foundation's footprint." }\end{array}$ \\
\hline $\begin{array}{l}\text { Other geologic structures } \\
\text { in abutments that threaten } \\
\text { the dam } \\
\text { (Structural geologist should } \\
\text { study available exposures at } \\
\text { damsite (one half of abutments } \\
\text { is still exposed) and review } \\
\text { results of USBR's mapping.) }\end{array}$ & $\begin{array}{l}\text { Many of the structures exposed are } \\
\text { interpreted as active or potentially } \\
\text { active faults and shears. Much of } \\
\text { evidence is based on unpublished } \\
\text { mapping and personal knowledge. }\end{array}$ & $\begin{array}{l}\text { Mapping has documented the origin, } \\
\text { nature, and history of deformation. } \\
\text { Shears and joints are restricted to } \\
\text { andesite porphyry and are related to } \\
\text { emplacement of andesite, not } \\
\text { younger faulting. There is no } \\
\text { evidence of through-going faults in } \\
\text { the foundation. }\end{array}$ \\
\hline
\end{tabular}


GEOTECHNICAL ISSUE

(and strategy for review)
OPPONENTS'

VIEW
PROPONENTS'

VIEW

\begin{tabular}{|c|c|c|}
\hline $\begin{array}{l}\text { Landsliding } \\
\text { (Landslide expert should study } \\
\text { damsite and review resuits of } \\
\text { USBR landslide-monitoring } \\
\text { program.) }\end{array}$ & $\begin{array}{l}\text { Landsliding could affect integrity of } \\
\text { east abutment or cause seiche in lake } \\
\text { which could lead to over-topping and } \\
\text { failure of dam. They cite } 1984 \text { EIS } \\
\text { report recommending more study of } \\
\text { landsliding. }\end{array}$ & $\begin{array}{l}\text { Potential landslide in abutments } \\
\text { would be buttressed by dam; dam has } \\
\text { adequate free-board to accom-modate } \\
\text { possible landslides into reservoir, and } \\
1987 \text { reactivation of landslide } \\
\text { downstream poses no threat. }\end{array}$ \\
\hline $\begin{array}{l}\text { Quality, alteration, and } \\
\text { permeability of foundation } \\
\text { rock } \\
\text { (Rock mechanics and } \\
\text { engineering geologists should } \\
\text { inspect abutment rocks and } \\
\text { review USBR documents.) }\end{array}$ & $\begin{array}{l}\text { Rock in foundation is weak } \\
\text { (crumbly), extensively sheared, and } \\
\text { fauited. Andesite porphyry has been } \\
\text { hydrothermally altered, not } \\
\text { weathered. Possible open cavities at } \\
\text { depth may threaten integrity of dam. } \\
\text { Concerned that grouting and } \\
\text { treatment of foundation will not } \\
\text { impede flow of water through rock.. }\end{array}$ & $\begin{array}{l}\text { Much of the foundation rock is } \\
\text { hydrothermally altered, but only } \\
\text { small volumes are intensely altered. } \\
\text { In general, the altered rock is tight } \\
\text { and is a suitable foundation for an } \\
\text { embankment dam. Grouting will } \\
\text { plug obvious fractures and provide an } \\
\text { impervious mantle on altered } \\
\text { bedrock. }\end{array}$ \\
\hline $\begin{array}{l}\text { Earthquake potential and } \\
\text { earthquake design criteria } \\
\text { (Review of seismotectonics } \\
\text { documents by Quatemary fault } \\
\text { expert, plus estimation of } \\
\text { probable ground motion by } \\
\text { expert) }\end{array}$ & $\begin{array}{l}\text { Statements imply belief that USBR } \\
\text { knows that a moderate to large } \\
\text { earthquake is inevitable in area of } \\
\text { dam. }\end{array}$ & $\begin{array}{l}\text { USBR design allows for } 3 \text { types of } \\
\text { earthquake: (1) a distant } M 7.5 \text { on } \\
\text { Wasatch fault zone, (2) an } \\
\text { intermediate-distance M } 6.5-6.75 \text {, and } \\
\text { (3) a random, local M 6.0-6.5. They } \\
\text { feel this is a reasonable design } \\
\text { criterion for the maximum credible } \\
\text { ground motion at damsite. }\end{array}$ \\
\hline
\end{tabular}




\section{GEOTECHNICAL REVIEW}

The U.S. Geological Survey agreed to review the adequacy of the USBR response to perceived safety concerns dealing with geotechnical issues at the Jordanelle damsite. We discuss these issues in separate sections of this report in the order tabulated above. We describe the nature and extent of the issues and make explicit and direct conclusions about their impact on safety of the dam. Discussions that support our conclusions are necessarily somewhat more technical than the conclusions. In this report, we use the following informal age divisions for the Quaternary (the past 1.65 million years): late Pleistocene $(10,000-130,000$ years ago), middle Pleistocene $(130,000-750,000$ years ago), and early Pleistocene (750,000 years to 1.65 million years ago). The Quaternary is comprised of the Pleistocene and the Holocene (past 10,000 years).

\section{ACTIVE FAULTS IN AREA OF ABUTMENT}

\section{INTRODUCTION}

Much of the concern over the long-term safety of the Jordanelle Dam, as expressed by opponents of the dam, rests on the possibility that surface rupturing or ground shaking associated with a large-magnitude $(M>6.5)$ earthquake may damage the structure and lead to its catastrophic failure. The consequences of such a failure could be catastrophic. Leon Hansen (written commun., 1991) has suggested that failure of the dam could flood much of the Heber Valley and lead to overtopping and subsequent failure of the Deer Creek Dam, which is located about 9 mi (15 km) downstream from Heber. From this point, floodwaters would pour down Provo Canyon and spread out across much of Orem and Provo, jeopardizing much of Utah Valley. Clearly, the potential, however remote, for active faulting at or near the damsite is being taken seriously by all parties concerned.

Investigations by USBR geologists, as well as previous geologic mapping, have demonstrated that much of the rock in and surrounding the dam's foundation and abutments has been subjected to faulting. This is not an unexpected finding, but the key question is whether or not any of the faults are capable of producing a damaging earthquake. Leon Hansen contends that the Cottonwood fault, which has been mapped as a reverse fault in Paleozoic and Tertiary rocks (Bromfield and others, 1970), is such an active fault. Moreover, USBR geologists (Sullivan, 1988a) have mapped a north-striking normal fault $0.4 \mathrm{mi}(0.6 \mathrm{~km})$ west of the west abutment of the dam. This newly recognized fault (the Bald Mountain fault) appears to have been active sometime before the late Quatemary 
(past 130,000 years), as evidenced by faulted sediments in one exploratory trench. A fault with a documented record of no movement in the past 130,000 years is not regarded as a likely candidate for movement in the near future owing to inherently long recurrence intervals and low slip rates. Finally, trenches at Jordanelle exposed many faults that cut poorly consolidated gravels; some of these faults might be young and potentially active.

To address whether faults in the Jordanelle area are active, the Panel reviewed the seismotectonic studies of Jordanelle Dam and Reservoir with specific reference to the Cottonwood fault, as well as other potential Quaternaryage fauits in the vicinity. USBR trench logs and field study of some of the remaining open-trench exposures at the Jordanelle damsite were particularly informative.

\section{THE COTTONWOOD FAULT}

For a number of years, Leon Hansen has suggested that the Cottonwood fault is an active, through-going structure capable of generating earthquakes. His basis for suggesting that the Cottonwood fault is young is its alignment with suspected faults having roughly the same northeasterly trend, which he feels are active on the basis of geomorphic expression, recent slumping, tracing faults upward to "the root zone" of soils, and the presence of fauit gouge. The Panel has no doubt that the Cottonwood fault is one of a family of northeast-trending faults and agrees that it may continue beneath rocks that form the foundation for Jordanelle Dam. However, the Panel disagrees with Hansen's inference of the age of the fault.

The USBR (Sullivan and others, 1988a) found no evidence of surficial expression of the Cottonwood fault or other faults in either abutment from their geomorphic and aerial-photography studies. A roadcut along the new alignment of U.S. Highway 40, directly west of Jordanelle, exposes the Cottonwood fault. It has an apparent dip of about $50^{\circ}$ to the north, strikes to the east, and is comprised of two main splays within a zone of deformation about $100 \mathrm{ft}$ (30 m) wide. The Weber Quartzite (Pennsyivanian) and sandstone and limestone of the Park City Formation (Permian) have been up-faulted southward over finer grained rocks of the Triassic Woodside Shale and Thanes Formation (Bromfield and others, 1970). Faulting has placed more resistant rock over less resistant rock, but the south-facing hillslope at the surface trace of the Cottonwood fault is relatively smooth. If the Cottonwood had been recently active, one would expect to see a steepening of slope at the fault trace. In addition, there is no geomorphic evidence of recent faulting on the flood plain and hillslopes adjacent to the Jordanelle damsite. Inasmuch as the USBR was cognizant of Quatemary faulting in the back valleys of the Wasatch Range, and because they had 
investigated a number of probable Quaternary faults as part of a larger study of seismotectonics for the Central Utah Project (Sullivan and others, 1988a), the Panel is confident that the USBR's seismotectonic investigations (Sullivan, 1988b) explored all evidence of surface faulting at the Jordanelle damsite.

Although there is no geomorphic evidence of recent surface rupturing along the Cottonwood fault, late Quaternary scarps along the Cottonwood fault could have been removed by erosion. This is a reasonable argument for areas where there is active erosion or mass wasting, such as at the west end of the west abutment. To evaluate whether the argument is valid, the USBR conducted a program of exploratory trenching along the projection of the trace of the Cottonwood fault, as mapped by Bromfield and others (1970).

\section{ACTIVE FAULTS IN THE RIGHT ABUTMENT OF THE DAM}

Before excavating the foundation and abutments for the dam, the USBR used bulldozers and backhoes to expose the geology of the west abutment. The USBR excavated 23 bulldozer trenches and nine supplemental backhoe trenches in a $560 \mathrm{ft}$ by $800 \mathrm{ft}(170 \mathrm{~m}$ by $245 \mathrm{~m})$ area. The results of these excavations were described in the USBR 1986 Technical Summary documents and in supplemental logs of trenches. During our first visit to the damsite, we inspected a number of the remaining open trenches in order to familiarize ourselves with the exposed stratigraphic and structural relations.

The trenches show clear evidence of faults that cut the Tertiary intrusive and volcaniclastic sedimentary rocks, and the overlying basin-fill sediment. In all of the examples that we saw, none of the faults cut the overlying surficial materials, which are comprised primarily of colluvium and locally derived piedmont alluvium of Quatemary age. The basin-fill sediment is interpreted as late Tertiary because of interfingering relations with the intrusive and volcaniclastic rocks, but the upper part of the basin-fill sediment may be as young 500,000 years according to the USBR (Sullivan, 1988b). This middle Pleistocene age estimate seems reasonable on the basis of regional studies of basin-fill stratigraphy and tephrochronology (volcanic ash studies) in the Keetley Valley. In several of the remaining trench exposures, there are faults that cut Tertiary materials and extend to or near the surface. During our first visit, Leon Hansen referred to such relations ("faults extending to the soil line") as evidence that the faults are young. However, we do not consider such relations to be diagnostic of young faulting for the following reasons: (1) faults in bedrock commonly are present at the surface owing to erosion of overlying materials; (2) unless a soil is formed in a younger (surficial) deposit, the presence of a fault in the soil or extending to the "soil line" is evidence only for 
movement that is younger than the bedrock that is involved (Oligocene, 26-38 million years, in this case); and (3) faulting that extends to the surface usually results in the formation of a fault scarp. Degradation of the scarp requires the deposition of material (fault-scarp colluvium) adjacent to the fault. This material (commonly referred to as a colluvial wedge) provides a demonstrable stratigraphic record of faulting. Paleoseismic studies of the surrounding region (Sullivan and others, 1988a; Machette and others, 1991) have documented the presence and usefulness of colluvial wedges for determining the prehistoric record of surface faulting events. In the Panel's cursory inspection, no stratigraphic evidence indicative of young (Holocene or late Pleistocene) faulting - specifically, geomorphic expression of faulting, faulted surficial deposits, or a stratigraphic record of faulting-was found in the numerous exposures at or near the west abutment of Jordanelle Dam.

\section{OTHER QUATERNARY FAULTS NEAR THE DAMSITE}

Recent mapping by the USBR (Sullivan and others, 1988a, 1988b), by the U.S. Geological Survey (Machette, 1989), and a soon-to-be-published compilation by the Utah Geological Survey (Hecker, in preparation; see also Goter, 1991) reveals a pattern of Quaternary faulting that is dominated by north-south-striking normal faults in the Wasatch Range and adjoining valleys. The majority of these faults are considered to be late Pleistocene or older, although Holocene faulting has been documented along the Wasatch fault zone and on several other faults. Paleoseismic investigations of the Wasatch fault zone show that it is the most active fault in Utah (Machette and others, 1991) and has produced a magnitude 7.0-7.5 earthquake once every 400 years, on the average, during the past 6,000 years. The Wasatch fault zone is comprised of discrete fault segments. The Salt Lake City segment, which bounds the eastern side of the Utah Valley about $20 \mathrm{mi}(32 \mathrm{~km})$ to the west of Jordanelle, is the closest segment of the Wasatch fault zone that could produce a large-magnitude earthquake. Most Quaternary faults in the region around Jordanelle, which are short and unspectacular in comparison to the Wasatch fault, bound valleys within the Wasatch Range.

\section{The Bald Mountain fault}

During investigations at Jordanelle, the USBR uncovered evidence of a Quatemary fault northwest of the west abutment. Geophysical investigations and drilling confirmed the existence of this fault, which became known as the Bald Mountain fault (Bald Mountain is about $3 \mathrm{mi}(5 \mathrm{~km})$ northwest of Jordanelle). Although the surface trace is 
not marked by vegetation alignments, lineations, or scarps, the discovery of a Quaternary fault just $0.4 \mathrm{mi}(0.6 \mathrm{~km})$ west of the west abutment of the dam warranted investigation.

The USBR excavated three trenches in surficial materials across about $0.6 \mathrm{mi}(1 \mathrm{~km})$ of the inferred trace of the Bald Mountain fault, as projected from adjacent bedrock and from subsurface drilling control. No evidence of Quaternary faulting was found in two of the three trenches (J-9 and J-13). However, trench J-10 revealed faulted basin-fill sediment, but the overiying Holocene deposits were undisturbed. Thus, evidence from trench J-10 allows an interpretation of surficial faulting in the past 500,000 years (youngest age of basin-fill sediment; Sullivan, 1988b), but before 10,000 years ago. From evidence in trenches J-9 and J-13, the USBR argued that late Pleistocene soils (estimated to be 130,000 years old) are not faulted elsewhere along the fault. Thus, on the basis of lack of surficial expression and unfaulted late Pleistocene soils, the USBR considers the last movement on the Bald Mountain fault to be pre-late Pleistocene in age $(>130,000$, but $<500,000$ years ago).

Although Quaternary movement is inferred on the Bald Mountain fault, it is not a candidate for probable surface rupture. The fault has a long recurrence interval (more than 130,000 years), as determined from the degree of development of soils on faulted basin-fill sediment (Sullivan and others, 1988b), and lacks geomorphic expression of late Quatemary displacement. If movement were to occur, the surface rupture would probably be along the postulated trace of the fault, which has a length of only $2 \mathrm{mi}(3 \mathrm{~km})$. The trace would be well upslope and northwest of the west abutment. Such faulting would be accompanied by seismic shaking (see following section on "Earthquake potential and earthquake design criteria").

Other late Quaternary faults in the vicinity of Jordanelle

Reconnaissance mapping, as part of the study of seismotectonics for the USBR' Central Utah Project, revealed the presence of several Quaternary and suspected Quaternary faults in the valleys within the Wasatch Range. Although these faults pose no surface rupturing threat to the dam, they could produce seismic shaking of the embankment materials if a large-magnitude earthquake were to occur on any one of them. In the vicinity of Jordanelle, no Quaternary movement has been documented on range-bounding faults in the Keetley Valley, other than on the aforementioned Bald Mountain fault. Faults that have known or suspected Quaternary displacement of similar age bound the eastern side of Kamas Valley (about $8 \mathrm{mi}(12 \mathrm{~km})$ to the east of Jordanelle) and the eastern side of Deer Valley (about $4 \mathrm{mi}(6 \mathrm{~km})$ to the northwest of Jordanelle). The faults that bound Round Valley, $12 \mathrm{mi}(20 \mathrm{~km})$ 
to the south of Jordanelle, appear to be late Quaternary (Sullivan and others, 1998b), and thus are the youngest faults in the valleys of the Wasatch Range. Because the Round Valley fauits are the closest faults that have been active in the past 130,000 years, the USBR considers them most likely to cause severe ground shaking at the damsite (see following section on "Earthquake potential and earthquake design criteria"). Although recent faulting is commonly assumed to signify increased earthquake potential (owing to inferred high slip rates), recent faults are only most likely to be reactivated if they have markedly shorter recurrence intervals than other faults in the region. Little or no information exists for recurrence intervals of faulting in the valleys of the Wasatch Range, at least in this region; thus one cannot improve on the USBR's assumption of potential activity of the Round Valley faults.

On August 26 and July 31, 1991, Leon Hansen sent us strongly worded statements regarding faults exposed in a quarry north-northwest of Hailstone, about one mile $(1.6 \mathrm{~km})$ north of the damsite. Hansen indicated that he was in possession of ample evidence justifying classification of at least one of the faults there as "active." Even though requested, Hansen provided us with no geologic evidence to substantiate his claim, and a brief visit to the quarry by two members of the Panel failed to reveal any evidence for active faulting. However, the excavations provided excellent exposure of a major west-northwest-striking fault mapped several years earlier by USBR geologists. As a point for comparison, a strand of the Lake Mead fault zone that has offset Tertiary volcanic rocks at least $12 \mathrm{mi}$ (20 $\mathrm{km}$ ) passes through the lake basin within $2 \mathrm{mi}(3.2 \mathrm{~km})$ of Hoover Dam, but poses no recognizable threat to the dam because the fault strand is not active.

\section{CONCLUSIONS-ACTIVE FAULTS}

The nearest major fault, the Cottonwood fault, is shown on published geologic maps as an east-trending reverse fault that displaces Tertiary and older rocks directly west of the damsite. Despite suggestions that the Cottonwood is an active fault that extends across the damsite, the Panel finds no definitive evidence that the fault is either young or crosses the damsite as a coherent recognizable geologic structure. The major displacement on the Cottonwood fault clearly predates intrusion of the Oligocene (26-38 million years old) andesite porphyry that makes up most of the dam's foundation.

Characterizations of the Cottonwood fault as an "active fault" are not supported by the scientific data acquired during the several years of research that have focused on this specific question, or by information supplied by opponents of the dam. No stratigraphic evidence indicative of young (Holocene or late Pleistocene) fault 
movement-specifically, geomorphic expression of faulting, faulted surficial deposits, or a stratigraphic record of faulting —were found on faults in the foundation or abutments of Jordanelle Dam, or in numerous exposures adjacent to the west abutment. The Panel agrees with the USBR's conclusion that movement on faults in the west abutment occurred before the late Pleistocene ( $>130,000$ years ago), and probably is much older than that. In addition, the possibility of hidden traces of an active fault beneath flood-plain deposits of the Provo River seems remote and scientifically untenable (see following discussion of "Geologic structures that may control. . . Provo River").

Quaternary movement has been documented on the 2-mi- (3-km-) long Bald Mountain fault, but this fault is unlikely to cause surface displacement. Evidence that this fault has been active before the late Pleistocene (>130,000 years ago) is circumstantial and found in only one of three trenches. If movement were to occur on the Bald Mountain fault, rupturing would probably be confined to the postulated trace of the fault, well upslope and northwest of the west abutment.

Although several faults in the valleys of the Wasatch Range produced surface offset during the Quatemary, they pose no surface-rupturing threat to the dam but could produce seismic shaking at the damsite. The nearest suspected active faults are those in Round Valley $12 \mathrm{mi}(20 \mathrm{~km})$ south of Jordanelle; they have produced surface ruptures in the past 130,000 years. In addition, the Wasatch fault zone has produced earthquakes as close as $19 \mathrm{mi}(30 \mathrm{~km})$ from the damsite. 


\section{GEOLOGIC STRUCTURES (FAULTS) THAT MAY CONTROL BURIED CHANNEL OF PROVO RIVER}

Preliminary investigations to determine the top of bedrock (Oligocene andesite porphyry and volcaniclastic sedimentary rocks) along the axis of the dam beneath the flood plain revealed a north-south-trending channel. Opponents of the dam suggested that this channel may be controlled by geologic structures (such as fauits) whose surface traces have either been removed by erosion or buried. To test this hypothesis, the USBR conducted several geophysical surveys across this supposed structure, parallel to the dam; they also drilled and cored the foundation rock for the same purpose. Although these studies showed no significant changes in stratigraphy across this channel, opponents argued that a near-verical fault could still be projected through the drill holes. To resolve remaining uncertainty, a program of angle drilling was conducted in 1986.

In preparing the foundation of the dam, the USBR excavated the alluvium-filled channel of the Provo River to bedrock and mapped the exposed footprint in detail (1:600 scale) These maps show a pattern of short, unconnected, northeast- and northwest-striking faults and shear zones, some of which are hydrothermally altered (see following discussion of "Faults in the dam foundation"). More revealing, however, was the lateral continuity of these structures, which cross the purported channel-controlling fault without apparent lateral or horizontal offset. The exposure of foundation rock in the channel eliminated the possibility that the position of the buried channel of the Provo River is fault-controlled.

\section{CONCLUSIONS-STRUCTURAL CONTROL OF PROVO RIVER}

The USBR studies revealed a sediment-filled channel of the Provo River that lies beneath the damsite. The hypothesis that the position of this channel is controlled by a north-south-trending fault is without scientific merit. Exposed and cleaned bedrock surfaces display structural continuity, thus proving that the postulated fault does not exist. 


\section{OTHER GEOLOGIC STRUCTURES IN DAM ABUTMENTS}

In the section on active faults, we approached the problem of the presence or absence of active faults from the youngest part of the geologic record. In this section, we approach the problem from the older (Tertiary) part of the geologic record for the purpose of evaluating what portions of the faults and other structural features at Jordanelle are likely to be so old that they are not candidates for being seismogenically active. This approach requires that we review salient aspects of the Tertiary geologic history of the area.

\section{TERTIARY GEOLOGIC HISTORY}

The Jordanelle area is located east of the region affected by east-directed thrust faulting of the late Cretaceous and earliest Tertiary Sevier orogeny. It is situated within an area affected by early Tertiary Laramide deformation, the nearest major structural element of which is the east-west-trending Uinta uplift. Major east-suriking faults in Paleozoic and Mesozoic rocks in the region may be related to the Laramide-age deformation that formed the Unita uplift, but details are lacking owing to a strong overprint by younger igneous activity. Oligocene igneous rocks that formed during this younger event are widespread in the Jordanelle region; these rocks include the Keetley Volcanics, which are locally as much as $2,700 \mathrm{ft}(1 \mathrm{~km})$ thick, and numerous genetically related shallow subvolcanic plutons, such as the andesite porphyry that is exposed in much of the dam's foundation and the nearby Mayflower stock. The thick sequence of volcanic rocks apparently accumulated in a structural depression between the Unita and Cottonwood uplifts. USBR geologists conclude that the main displacement on a major fault near the damsite, the Cottonwood fault, is related to the emplacement of the Mayflower stock, and that this displacement predates intrusion of the andesite porphyry that makes up most of the dam's foundation.

Jordanelle is in the southern part of the Keetley Valley, one of several structurally controlled valleys within the Wasatch Range that, together, form an elongate, north-south belt that extends parallel to and east of the Wasatch fault zone and associated Wasatch Front. Miocene and younger faulting along the Wasatch and associated faults has resulted in the characteristic basin-and range-physiography of the eastern Great Basin, the block-like uplift of the Wasatch Front, and the valleys to the east. Most of this physiography reflects normal faulting resulting from westward-directed extension. 


\section{ORIGIN OF THE ANDESITE PORPHYRY}

Two main types of Tertiary rock are present in the dam foundation and abutments: (1) nonbedded andesite porphyry (about 90 percent), and (2) bedded rocks with volcanic affinities (about 10 percent). The bedded rocks are strongly tilted and faulted in the vicinity of the damsite. The extrusive-versus-intrusive origin of the andesite porphyry and the relative age of the two rock types are important in determining the Tertiary structural history of the foundation area which, in tum, is relevant to the history and range of potential hazards that can be reasonably assigned to the Cottonwood fault or other potentially active faults in the area. The following two hypotheses may help to show why this is so.

1. If both rock types are part of a layered stratigraphic assemblage of coeval bedded volcaniclastic rocks and extrusive lava flows, the entire assemblage must have been subjected to the strong stratal tilting and faulting to which the bedded volcaniclastic rocks have been subjected. In this case, much of the movement on the Cottonwood fault could be young, unless evidence exists to the contrary.

2. If, on the other hand, the andesite porphyry intrudes the bedded volcaniclastic rocks, their tilted and faulted condition could have been produced during and directly following intrusion which, in turn, could postdate all significant displacement on the Cottonwood fault.

In written documents and in discussions, Leon Hansen expressed strong concerns about whether the andesite porphyry in the dam foundation is of extrusive or intrusive origin and about the USBR's inconsistency, over the duration of the Jordanelle project, regarding the mode of origin of the andesite porphyry. Whether the andesite porphyry originated as an extrusive or shallow intrusive body is of no apparent consequence either to the integrity of the rock and its suitability as foundation material or to potential problems posed by physical properties of its contacts with other rocks (see the following discussion of "Foundation rock quality, alteration, and hydrologic characteristics"). However, as noted in the previous paragraph, it is important in deciphering the structural history of the damsite. Therefore, we note here some observations that tend to confirm the interpretation by the USBR and its consultants. They favor an intrusive origin for the andesite porphyry at the damsite.

In the exposures the Panel observed, most of the andesite porphyry has a conspicuously uniform, coarsely porphyritic texture and lacks oxidized, vesiculated, or autobrecciated zones-features that are typical of lava flows. In the newly exposed south-facing part of the west abutment, we found three steep northwest-striking zones a few 
centimeters to a few tens of centimeters wide that show strong variations in grain size from the normal texturally uniform porphyry to very fine-grained, apparently nonporphyritic, rock of presumed similar composition. These textural variations apparently mark steep contacts across which all rock is dense, highly lithified, nonbrecciated, unoxidized, and nonvesiculated. The Panel concludes that these are partially chilled intrusive contacts, analogous to the steep northwest-striking intrusive contact observed by USBR consultant Myron Best (1986) near the south boundary of the andesite porphyry in the middle west abutunent. These contacts indicate that the andesite porphyry at the west abutunent is a compositionally uniform, but composite, intrusive body.

Beneath the central part of the dam, an inclined drill hole (DH-548) crosses at least three contacts between andesite porphyry and volcaniclastic rock. In our study of core recovered from two of the contacts, we did not see any features common to extrusive flows. The contacts are very tight and show a minor decrease in grain size toward the volcaniclastic country rock, again suggesting an intrusive origin for the andesite porphyry.

In three separate excavations on and adjacent to the east abutment, we observed features at contacts between andesite porphyry and bedded rocks of the Keetley Volcanics indicative of an intrusive origin for the andesite porphyry. The most convincing is an excavation at the northern end of the emergency spillway where the andesite porphyry cuts across bedding in volcaniclastic sedimentary rock. The andesite porphyry has a 50-70-cm-wide steep, irregular, foliated fine-grained, chilled zone against the sedimentary rock, indicating an intrusive origin.

In summary, on the basis of contact relationships throughout the damsite, the Panel concludes that the andesite porphyry that forms about 90 percent of the dam's footprint is an intrusive mass-a conclusion that is consistent with (1) the varied and comprehensive observations reported by Best (1986), (2) comparisons made by R.H Merrium, consultant to the USBR (1980), of rock textures in the andesite porphyry to other shallow intrusives in the worid, and (3) ground-magnetic and aeromagnetic data indicating an intrusive mass beneath the dam's axis with at least $4,000 \mathrm{ft}(1,220 \mathrm{~m})$ of depth extent as report by USBR consultant Fox (1984). This interpretation allows virtually all of the displacement on the Cottonwood fault to predates intrusion of the andesite porphyry that cuts across the fault zone. Emplacement of the andesite porphyry probably caused much of the deformation in the Keetley Volcanics where they form the surrounding country rock. 


\section{POST-INTRUSION FAULTS IN THE DAM FOUNDATION}

Acceptance of an intrusive origin of the andesite porphyry allows for, but does not require, a pre-intrusive age of displacement on the Cottonwood fault or other faults in the area. Any effects of post-intrusion faulting should be visible within the exposed andesite porphyry or at its contacts with other rocks. Experts who have studied the foundation area agree that such faults exist, and USBR mapping confirms their presence. There is, however, much disagreement on the location, continuity, significance, and age of these faults. The chief disagreement centers on whether or not major young faults pass through the foundation. Most of the rock critical to resolving this disagreement was covered by embankment materials prior to our first visit. Therefore, for one side of the disagreement, the Panel relied on projections of faults to the central part of the foundation from nearby mine workings, roadcuts, trenches, and natural exposures, as well as projections of topographic lineaments. For the other side, the Panel used maps, photographs, descriptions, and reports resulting from drilling and excavation, as well as detailed maps of the nearly completely exposed foundation supplied by the USBR. The Panel notes that this degree of exposure of foundation rock is unique and, when combined with the subsurface drill-core network, provides a rare opportunity to assess the presence or absence of critical structures, such as major through-going faults. In the paragraphs that follow, we review evidence from the exposed foundation and from drill holes that bears on the location and continuity of faults, and the indirect evidence indicating that much of the faulting is old (Tertiary) and does not represent a major post-intrusion deformational episode.

\section{Location and continuity of faults}

The USBR's detailed maps of joints, shears, and faults in the foundation reveal discontinuous structures that form a blocky or mosaic pattem arising mainly from the intersection of east-northeast and north-south to nonthnorthwest striking joints and faults. USBR investigations have emphasized the lack of through-going faults or fault zones, such as the Cottonwood fault and the F-10 faults. Our review tends to confirm this aspect of fault terminations in the foundation area. The Panel observed two of the more conspicuous steep north-striking faults in the large, newly exposed south-facing excavation at the west abutment that appeared to us to be the most likely candidates for classification as through-going faults that might have significant displacement. However, our attempt to trace these faults southward across the floor of the excavation showed that they terminate abruptly within the exposed foundation rock. Although the nature of the terminations was not determined, the discontinuous aspect of 
these faults is consistent with the general pattern of intersecting fractures that are part of the carefully mapped mosaic pattern in the andesite porphyry elsewhere in the foundation area. It is also consistent with the general observation of USBR geologists and their consultants that displacement on the faults ends abruptly as they are traced from the andesite porphyry toward contacts with adjacent country rocks.

The strongest evidence for the discontinuous nature of the faults in the dam foundation is (1) the lack of correlation of faults from drill hole to drill hole within the network of holes drilled across the foundation, and (2) the general lack of correlation of faults mapped on the surface of the cleaned foundation with those intercepted by drill holes, especially the system of inclined drill holes. This well documented discontinuous nature shows that the projections of faults, such as the Cottonwood fault, through the foundation from localities beyond the foundation is scientifically unsound unless supported by direct evidence.

The excellent examples of fault terminations and mosaic patterns mapped in detail in the dam foundation provide a basis for understanding faults, such as the F-10 fault, that are much more conjectural than the Cottonwood fault. The existence of the F-10 fault was conjectured by USBR geologists on the basis of indirect evidence such as drillhole and magnetic data. The drill-hole data indicated a need for a fault to explain an anomalously low elevation of the bedrock-alluvium contact in part of the reservoir basin north of the dam. A northeast-striking, east-side-down, graben-bounding, Basin and Range-type fault with Quatemary displacement was postulated in 1984-1985 by USBR geologists. At that time the USBR acknowledged two problems with their postulation: (1) no complimentary fault could be found in the east abutment to bound the graben on the east, and (2) displacement on the F-10 fault apparently decreased southward toward the damsite. To resolve these problems, USBR geologists postulated an eastwest structure north of the damsite against which the graben terminates southward. At the same time, R. L. Bridges (1984) postulated (on the basis of his connecting exposures of faulted rock at Hailstone with faulted rock south of the damsite 2 miles away) that the F-10 fault passes through the damsite. It is important to note that neither the direction nor amount of displacement are consurained by offset of stratigraphic markers anywhere along this postulated fault. After complete exposure of the dam's footprint, detailed mapping by the USBR failed to identify the F 10 fault as a through-going structure in bedrock or, more important, as a feature offsetting the bedrockalluvium contact. After having developed an understanding of the nature of fault terminations and the mosaic fault 
pattern, the USBR, having previously postulated such termination for the F 10 fault, lost interest in it as a structure with which they need be concerned.

Although the lack of through-going faults precludes projection of a large-displacement fault (such as the Cottonwood) through the foundation as a single fault, it does not preclude the possibility that (1) somehow large displacement is dispersed through the andesite porphyry along many elements of the mosaic pattern, or (2) large displacement is transferred from the Cottonwood fault to the contact between the andesite porphyry and its country rock and, thus, somehow is deflected around the intrusive body. The first possibility has not been advanced by opponents to the Jordanelle dam, and the Panel does not consider it likely (see discussion of hydrothermal alteration in subsequent section of this report). The second possibility was recognized by Best (1986). The USBR's detailed maps, trench logs, drill logs, photographs, and descriptions, as well as our field review, produced considerable evidence of post-intrusion deformation at the south margin of the andesite porphyry in the middle of the west abutment (the zone referred to as SZI by the USBR). The rocks are broken and sheared along the contact. This deformation could be taken as evidence for some sort of accommodation for displacement on the Cottonwood fault, but not as evidence that the Cottonwood fault passes through the dam foundation. Bridges (1984) suggested that the deformation results from uplift of the Jordanelle stock (andesite porphyry) subsequent to its emplacement and solidification.

\section{Age of faulting}

In a 1990 summary report on foundation conditions at the Jordanelle dam, Douglas Campbell (a member of the most recent Consulting Group) made several very cogent observations that have a strong indirect bearing on estimating the age of many of the faults in the foundation. He noted that many structures originally thought to be broad shear zones are actually fracture-controlled zones of hydrothermal alteration within which the parent rock is largely converted to clay. He also noted that much of the altered (clayey) rock, which should be highly susceptible to shearing and development of a shear fabric, lacks evidence of post-alteration shearing. He concluded that the rocks remain largely undeformed subsequent to alteration. The Panel studied one conspicuous east-striking, steep zone of bleaching that is 6-10-ft (2-4-m) wide in the east abutment (designated ST5 by USBR) and found that it marks a zone of hydrothermal alteration along a fault zone. Normal displacement (throw) of weak layering in the north side of the zone is less than $3 \mathrm{ft}(1 \mathrm{~m})$, and total throw is probably less than $10 \mathrm{ft}(3 \mathrm{~m})$. Individual fractures in ST5 are only 
on the order of a tenth of an inch (a few $\mathrm{mm}$ ) wide and are tight, although they clearly served as a channelway for hydrothermal fluids that attacked and partially altered the wall rock to clay minerais. There is no evidence of postalteration displacement on ST5. These structural relations support Campbell's conclusion that alteration was faultcontrolled and that little, if any, faulting postdates the alteration.

If the time of the alteration can be established, much of the faulting can be reasonably interpreted to predate it. The hydrothermal aiteration at Jordanelle requires long-term upward movement of hot aqueous fluids, a process common in country rock above crystallizing magma chambers. Most episodes of hydrothermal alteration are closely tied to an underlying intrusive body, and may continue for several million years or until the source of heat is dissipated. The Panel considers it likely that the hydrothermal alteration at Jordanelle accompanied the Oligocene igneous activity that is well documented in the region and as was suggested by Campbell (1990). All faults that served as channelways for hydrothermal fluids must be at least that old. The control exerted by faults on the distribution of altered rock seen in the plan-view map of the dam foundation (scale 1:1,200) suggests that most faults and joints in the foundation must be coeval with the igneous episode, and thus are of Oligocene age (26-38 million years ago).

Exceptions to the general absence of post-alteration displacement were noted in the newly exposed south-facing excavation in the west abutment where fault zones with steep to moderate dips and north to north-northwest strikes contain fragments of hydrothermally altered rock that float in reddish-gray gouge. This relation suggests postalteration displacement on these faults. However, as noted in the previous subsection of this report, we were unable to trace these same faults across the floor of the excavation. USBR geologists are currently mapping these faults in detail. The Panel does not consider these faults to be a threat to the safety of the dam because they are discontinuous, do not lie along any mapped major faults, and are not known to have been active in the late Quaternary (from photogeologic and trenching studies).

The Panel concludes that most faults in the intrusive andesite porphyry of the foundation of the dam formed during the Oligocene episode of igneous and hydrothermal activity and have since been essentially inactive. Some faults that are currently being studied in the west abutment show evidence of younger displacements, but we do not consider them to be a threat to the dam. 
Relation between the Cottonwood fault and faults in the dam foundation

We note above that deformation at the south margin of the andesite porphyry could be taken as evidence for post-intrusion accommodation for displacement on the Cottonwood fault, but not as evidence that the fault passes through the dam's foundation. Many of the east-northeast- to northeast-striking faults that cut the andesite porphyry in the foundation lie along reasonable (northeastward) projections of the Cottonwood fault. Because of their location and trend, and because they tend to be more highly concentrated along reasonable projections of the Cottonwood fault than elsewhere in the foundation, the Panel interprets them as indicating post-intrusion displacement on the Coutonwood fault. Several of these faults controlled the distribution of hydrothermal alteration by serving as channelways for long-term upward movement of hydrothermal fluids. As we note in the previous section of this report, these faults are most likely Oligocene in age and show litule, if any, evidence of younger displacement. In particular, excavation of the bedrock-alluvium contact along the full width of the foundation failed to reveal evidence of geologically young fault offset of that critical contact.

\section{CONCLUSIONS-OTHER GEOLOGIC STRUCTURES}

There is strong evidence that the andesite porphyry was intruded across the Cottonwood fault in Oligocene time (26-38 million years ago). After solidification, there was renewed faulting, possibly including renewed movement on the Cottonwood fault. The andesite porphyry along the projection of the Cottonwood fault was cut by many faults, thus forming a complex intersecting mosaic pattern. These post-intrusive faults are conspicuously discontinuous as revealed by detailed mapping and closely spaced drill holes. These faults served as channelways for migration of hydrothermal fluids during the episode of igneous activity in the Oligocene. However, the absence of a well-developed shear fabric in these altered rocks suggests litule, if any, displacement on most of the faults since Oligocene time. On the basis of the well-documented, discontinuous nature of the post-intrusive faults and indirect evidence that the faults are old (Oligocene), the Panel concludes that no faults with major young displacements can be projected through the foundation of the dam.

Exceptions to the predominandy Oligocene faulting are found in the west abutment where steeply and gently dipping faults with generally north-northwest strikes show evidence of post-alteration displacement. These faults are also discontinuous within the area of the abutment. They are currently being mapped by the USBR. Although the timing of movement on these faults cannot be constrained any closer than Oligocene or younger from the exposures 
in the foundation, none of them appear to be associated with faulting at the surface as shown by trenching and preexcavation USBR aerial photography. The Panel does not consider these faults a seismic threat to the dam because there is no direct evidence that they are continuous with major faults that have been active recently.

\section{LANDSLIDE HAZARDS}

\section{INTRODUCTION}

Landslides have been a continuing problem in the valley of the Provo River. During historic time, landslides commonly have been caused by periods of abnormally high precipitation (both snow and rain), such as occurred in 1982-85. In 1930, 1931, and 1938, major landslides dammed the Provo River in Provo Canyon, some 20 mi (32 $\mathrm{km}$ ) downstream from the Jordanelle damsite. Because of this past history of landsliding in the area and along the valley walls of the Provo River, it has been suggested that there is a hazard to Jordanelle Dam and Reservoir from future landslide activity. As a result, the Panel carried out a technical reconnaissance and airphoto interpretation of the valley wall in the vicinity of Jordanelle Dam and along the shoreline of the future Jordanelle Reservoir with the goal of noting possible landslide hazards.

We will discuss the possibility of landslide activity at Jordanelle Dam and Reservoir due to the filling of the reservoir and fluctuation in reservoir levels, and the effect that these landslides might have on the integrity and safety of the dam, reservoir, and appurtenant structures. Potential landslides and their effects will be discussed for three segments of the Provo River and its tributaries: (1) directly downstream of the dam, (2) at the dam, and (3) along the shoreline of the future reservoir. 


\section{LANDSLIDE HAZARDS DOWNSTREAM FROM THE DAM}

The valley walls of the Provo River directly downstream from Jordanelle Dam are steeply incised (maximum slopes of about $35^{\circ}$ ) in volcanic breccia and andesite of Tertiary age. The volcanic breccia is susceptible to landsliding, some of which has occurred during the past 10 years. In addition, there are several scars on the valley walls that were caused by prehistoric landslides.

On the west valley wall, a large snowmelt-triggered rockslide occurred in volcanic breccia in 1984 about 4,000 ft $(1,220 \mathrm{~m})$ downstream from the centerline of Jordanelle Dam. This 10-acre (4-ha) slide, which partially blocked the Provo River, apparently moved slowly; instrumentation monitored by the USBR has indicated no subsequent movement since 1984. There is a possibility of renewed activity of this slide during periods of future heavy precipitation or seismic activity, but it is far enough downstream that it poses no threat to Jordanelle Dam or Reservoir. This slide, which was caused by weakening of the valley wall by ground water from snowmelt, probably is typical of the worst type of slide that might be expected to occur in the valley walls upstream from the dam during filling of the reservoir. Although such slides can be fairly large, they do not attain sufficient velocities to produce destructive waves in the reservoir.

Abnormally warm weather, rain, and wet snow in February 1986 resulted in flooding and samurated soil conditions along the Provo River at the site of Jordanelle Dam. This excess water caused surficial slips and mudflows at the surface of older landslide debris, "pyroclastic" rocks, and soils a few hundred feet downstream of the east abutment of Jordanelle Dam. The scars from these surficial slips and mudflows are still evident on the valley wall. Because they are downstream from the dam, reactivation would pose no hazard to the dam or reservoir. Although these slips and mudflows would cross the alignment of the emergency spillway, no damage or blockage is likely to occur because this section of the spillway has a covered, box-type construction. If deeper landslides occurred in this area, the spillway could be damaged; however, it could be repaired without affecting the integrity of the dam itself.

A large prehistoric landslide headscarp is evident at the top of the east valley wall at a distance of about 800 $1,700 \mathrm{ft}(245-520 \mathrm{~m})$ downstream from the centerline of the dam. Below the headscarp, there is evidence of small prehistoric landslides. These slides did not reactivate during the 1982-85 wet cycle and are unlikely to fail again. 
But if they do move again, they are far enough downstream that they pose no danger to the dam. At worst, they would damage the emergency spillway, which would not affect the dam or reservoir.

\section{LANDSLIDE HAZARDS AT THE DAM DAMSITE}

The east abutment area exposes a regularly jointed rockmass of unweathered and unaitered andesite porphyry. In the area where the core material of the dam will be placed, shallow-dipping joint surfaces intersect with steeply dipping, slightly overhanging joint surfaces to form a stepwise arrangement of large blocks. Downdip movement of these blocks is of little consequence and is apparent only along the leading edges of the steps. A blocky exposure of jointed andesite (approx. 100,000 cubic yards; $76,500 \mathrm{~m}^{3}$ ) directly downstream from the core area, commonly referred to as the "rock slide," appears to rest on low-angle westward-dipping joint surfaces. This rock exposure has been instrumentally monitored by the USBR since 1987 , and no movement has been detected. Potential for any future movement, however unlikely, will be further reduced when the rockmass is fully buttressed by the downstream shell of the dam.

A set of low-angle, rotational failure surfaces is exposed in highly fractured Tertiary andesite porphyry on the steep, south-facing slope of the west abutment near USBR station 8, which is directly upstream from the crest of the dam. Surficial gravitational movement may have occurred on these failure surfaces in the past. Because no headscarps are in evidence in the alluvial slopes above the features, any movement must have been prehistoric and probably pre-Holocene in age. From the attiude of the failure surfaces and the geologic relations exposed in the west abutment, it appears that the mass of igneous rock on top of these potential slide surfaces will be almost completely buttressed and enveloped by the upstream shell of the dam. Therefore, if activation or reactivation as gravitational slides were to occur during the filling of the reservoir (or during fluctuation in reservoir level), the safety of the dam would not be affected.

The Tertiary-age Woodside shale is exposed in the valley wall a few hundred feet downstream of the dam and $100-300 \mathrm{ft}(30-90 \mathrm{~m})$ above the west abutment. Small prehistoric landslides occur in the weak strata of the Woodside shale, but this unit does not crop out in the dam foundation. Any future landsliding in the Woodside shale would be safely downstream from the dam. 


\section{LANDSLIDE HAZARDS ALONG THE RESERVOIR SHORELINE}

Jordanelle Reservoir will store 320,000 acre-ft $(25,900$ ha-m) of water at its active storage capacity. The landforms along its $28-\mathrm{mi}(45-\mathrm{km})$ shoreline range from gently sloping alluvial terraces to steep (as much as $45^{\circ}$ ) slopes in volcanic rocks. The Panel conducted a field and airphoto reconnaissance of this shoreline looking for evidence of landslide activity - prehistoric, historic, or current. We made note of slopes that might be susceptible to landsliding during or after the filling of the reservoir. The following discussion of landslide susceptibility divides the shoreline into three areas: (1) the southeastward-flowing reach of the Provo River from Jordanelle Dam to the site of Hailstone, (2) the westward-flowing reach of the Provo River from the head of the reservoir to the site of Hailstone, and (3) Drain Tunnel Creek, upstream (north) of Hailstone.

\section{Provo River-Jordanelle Dam to Hailstone}

The east valley wall in this stretch (along the east-abutment haul road) is steeply incised into andesite and volcanic breccia. Slopes as steep as $45^{\circ}$ exist at the foot of the valley wall for about a mile $(1.6 \mathrm{~km})$ upstream from the dam. Most of the material forming these steep slopes is a stable andesite which itself is not susceptible to landsliding, but minor raveling of slopes should be expected during filling of the reservoir. This raveling will be on a small enough scale as to have very little effect on the reservoir; it poses no threat of causing a wave that might endanger the integrity of the dam.

The shoreline at maximum-reservoir stage will be mainly in volcanic breccia on slopes of $15-20^{\circ}$; landslides should not be expected on these slopes. However, the breccia is not a very strong material, and where local slopes are steeper than $15^{\circ}-20^{\circ}$, minor slumping/sliding should be expected, particularly with seasonal fluctuation of lake level. These slumps/slides will not be large, nor will they move with high velocity; thus, they will have little effect on the reservoir and none on the dam.

The northwest side of the valley between Jordanelle Dam and Hailstone consists mainly of gently sloping alluvial terraces that will not generate major landslides either during or after reservoir filling. If any slides do occur on the faces of these terraces, they will be shallow and small and will not affect the reservoir or dam. 


\section{Provo River Upstream from Hailstone}

This part of the valley is incised mainly in volcanic breccia, which is susceptible to landsliding where it forms steep slopes. The southern (north-facing) wall of the valley is generally steep (maximum slope about $35^{\circ}$ ); the northern valley wall is less steep, commonly $20^{\circ}$ or less. There is evidence of at least two large prehistoric landslides in the volcanic breccia-one on the south valley wall in sec. 33 and the other on the north side in sec. 34 . Neither of these slides shows any evidence of recent activity. Because the volcanic breccia is not a strong rock, some minor sliding and raveling will probably occur on the steep south valley wall during filling of the reservoir and fluctuations in water level after filling. However, there is no reason to expect any large, high-velocity slides.

Very little future landslide activity is expected along the less-steep northem side of the valley. Activity will probably be limited to small failures on locally steep slopes. It should be noted that if any large slides do occur along this stretch of the reservoir, they will move in a north to south (or south to north) direction, and any waves produced will move mainly in that direction and dissipate against the opposite valley wall. There is no chance that a wave of destructive height and force caused by a slide in this part of the valley would move downstream and turn the comer to reach Jordanelle Dam.

Drain Tunnel Creek Upstream from Hailstone

Except for a 2-mi (3.2-km) stretch of strong intrusive rock that forms the east valley wall (general slope $10^{\circ}$ $1^{\circ}$ ) of Drain Tunnel Creek between Hailstone and Keetley, the shoreline of the reservoir on Drain Tunnel Creek will be on gently sloping (less than $10^{\circ}$ ) alluvial terraces. The slopes in the intrusive rock will not be subject to landsliding because the rock is strong and the slopes are only moderately steep.

A few very small, shallow slips occurred on the faces of the alluvial terraces directly west of Keetley during the period of extreme precipitation of 1982-85. It is possible that these failures will be reactivated during reservoir filling, but they are too small and would be too slow-moving to have any effect on the reservoir. 


\section{CONCLUSIONS-LANDSLIDE HAZARDS}

There is no evidence of recent (Holocene) landsliding in the foundation of Jordanelle Dam, and there is no substantive evidence to indicate potential for landsliding that would damage the dam. Rocks that lie above low-angle slip surfaces in the north side of the west abutment will be almost entirely buttressed by the embankment, thereby preventing any possibility of failure into the reservoir.

Although minor landslide activity along the shoreline of Jordanelle Reservoir is to be expected during reservoir filling and during post-filling fluctuations of reservoir level, there is no indication that any of the slides will be large enough or of high-enough velocity to form waves that could overtop or damage the dam.

Continued landslide activity downstream from the dam could result from periods of heavy precipitation in the future. The only structure related to the Jordanelle damsite in this area is the emergency spillway. Because the spillway is covered, it is not likely to be damaged by shallow landslides. If damaged by deeper landslides, it could be repaired without affecting the integrity of the dam itself.

\section{QUALITY, ALTERATION, AND PERMEABILITY OF FOUNDATION ROCK}

The Panel's review confirms the findings of the USBR and its consultants that most rocks at and directly adjacent to the dam foundation are cut by faults, and that fault spacing in the west abutment is much less than in the east abutment. These faults dip at a variety of angles, and range from steep to relatively shallow. Faults or fault zones in the foundation of an embankment dam do not necessarily pose a safety threat to the dam: they are a potential threat if they are active, are channelways for significant fluid flow, or are characterized by damaged rock that is so weak that it cannot withstand superimposed loads. As a point of comparison, the volcanic tuffs, breccias, and flows that form the abutments for Hoover Dam in southern Nevada contain an estimated minimum of two million slickensided faults per cubic mi (one-half million per cubic km).

During our field review we briefly sudied several well-exposed faults to evaluate their influence on foundation strength and (or) permeability. The most continuous faults and presumably those having the largest displacements are marked by gouge and strong shear fabric in zones that are generally less than 2 in $(5 \mathrm{~cm})$ wide. These zones grade outward through fractured and, locally, brecciated rock to intact rock within a distance of 3-10 ft (1-3 m). Faultdamaged rock forms irregular, prismatic, or lensoid masses where it has either collected at fault bends or been excised 
at fault intersections. Shear fabrics in these masses are commonly discordant to the boundary shears, indicating rotation. Also, some shears internal to the masses of fault-damaged rock are truncated at the boundary shears. These features indicate a protracted displacement history, the youngest elements of which are the through-going shears that traverse the excavations. The fault-damaged rock is progressively weaker (less resistant to excavation) toward the center of discrete shear zones. In no fault or fault zone that we observed is the fault-damaged rock likely to be weaker than the embankment materials or weak enough to collapse or seriously compress under the influence of the embankment. Concems over the strength of fault-damaged rock should be relieved by the results of index texts of the strength of foundation rock (USBR, 1986). These tests, which include tests on fault-damaged rock, show a wide range of values (965-35,300 psi; 7-243 MPa), but with an aggregate average strength of $13,900 \mathrm{psi}$ (96 MPa). Such strength values characterize the foundation as strong, solid, and capable of supporting the weight of the embankment dam.

Leon Hansen has repeatedly characterized the volcanigenic sedimentary rocks of the Keetley Volcanics as "mudash deposits" and inferred that they are inherently unsuitable as foundation materials. The USBR conducted 60 pointload strength tests and 20 unconfined compressive strength tests on rocks of the Keetley Volcanics (including andesite autobreccia, lapilli wff, lapilli breccia, and sedimentary breccia) at Jordanelle (USBR, 1986, v. II, Engineering Geology, p. 54). The specific range of variability for the Keetley Volcanics is $678-21,300$ psi from point-load tests and $700-8,000$ psi for unconfined compressive tests. The range of average values for the four separate rock types that make up most of the Keetley Volcanics is $3,600-6,300$ psi for point-load tests and 3,8005,1000 psi for unconfined compressive tests. These results show that, as a group and as separate map units, the rocks collectively referred to as "mud-ash deposits" and which comprise only a small percentage of the foundation of the dam have adequate strength to support an embankment dam.

Concern has been expressed over the allegedly high permeability of the foundation rock of the Jordanelle Dam and whether treatment of permeable zones in the foundation has been adequate. With respect to the Teton Dam failure, these points are of concern to both the local populace and the scientific and engineering community. During our two visits to the damsite, members of the Panel inspected a number of fault, shear, and alteration zones, mainly in the abuments of the dam (the base of the foundation was largely covered). We observed no fault-damaged rocks with openings that could serve as conduits for the kind of rapid fluid flow that would compromise the integrity of the 
dam by erosion at the embankment-foundation interface. Nor did inspections of the flood-plain section of the foundation by consultants to the USBR disclose any potential open conduits. The grouting procedures implemented by the USBR - especially the excavation and insertion of grout keels along zones of hydrothermally altered or faultdamaged rock-will reduce access of impounded waters to any potential open conduits and reduce seepage to manageable levels.

Concerns have been expressed as to whether or not "enhanced" matrix permeability and/or flow through channels in the faulted and altered portions of the foundation will cause the foundation to leak. This issue has been addressed by mapping and characterization of the thoroughly cleaned and fully exposed "foot print" in the east and west abutments and flood plain, and the findings are detailed in the 1990 reports of the Consulting Group to the USBR. Some rocks that have been extensively altered to clay have lower permeability than unaitered rock. The amount of grout used in the construction of grout curtains along the full length of the foundation indicates that the connectivity along the joints and faults in the andesite is low to nonexistent. Along the downstream grout curtain (which is designated as line 4), the consumption of grout per foot of hole is 0.51 bags in the west abutment, 0.19 bags in the flood plain, and 0.16 bags in the east abutment (USBR unpublished computer printouts and engineering drawings). These grout-consumption values indicate a low-to-nonexistent fracture connectivity. (For purposes of comparison, an empty 3-in.- (8-cm-) diameter hole will require about 0.05 bags of grout per $\mathrm{ft}$ of depth.) Along the toe region of the west abutment, the grout intake locally increased to $0.78 \mathrm{bags} / \mathrm{ft}$, whereas along a parallel section of the upstream grout curtain (which is designated as line 3.5 ) the grout intake was only 0.09 bags $/ \mathrm{ft}$.

The low-to-nonexistent fracture connectivity indicated by the aforementioned grout consumption records is consistent with the low degree of fracture connectivity revealed in detailed maps of the andesite porphyry in the foundation, as well as the general tendency for faults in the andesite porphyry to terminate abruptly at or near contacts with country rock. Even the largest faults characterized by shear fabrics and slickensides (classified as B2 shears by the USBR) show this characteristic lack of connectivity. That this characteristic extends into the subsurface to depths of at least $300 \mathrm{ft}$ (about $100 \mathrm{~m}$ ) beneath the dam is verified by vertical and inclined drill holes that form a drill-hole curtain along the dam's axis. Cores recovered from some of the most fault-damaged intervals (the B2 shear zones) directly beneath the dam exhibit litule or no evidence of either pervasive shear fabric or extensive breccia. The zones appear tight with sparse striated surfaces bounding $1 / 2-$ in. $(1-\mathrm{cm})$ size fragments and no 
suggestions of thick gouge. Moreover, shear zones cannot be correlated from one drill hole to another or from drill holes to mapped surface structure. These findings confirm the USBR conclusion that the faults and shear zones are a locally developed and somewhat random network of non-connected to poorly connected fractures. Collectively, these fractures will not cause the foundation to leak beyond levels that the design can accomodate.

An unplanned permeability test occurred when the USBR excavated alluvium from the sediment-filled channel of the Provo River to about $80 \mathrm{ft}(25 \mathrm{~m})$ beneath the flood plain of the Provo River (see previous discussion of "Geologic structures that may control. ... Provo River"). Bedrock exposed in the walls of the channel through the foundation of the dam yielded extremely low seepage rates, confirming the generally low permeability of the foundation rock.

\section{CONCLUSIONS-FOUNDATION ROCK}

From an engineering standpoint, bedrock in the dam's foundation has not been significantly weakened by faulting, nor by hydrothermal alteration. The clayey alteration products resulting from the Oligocene-age hydrothermal alteration have tended to make former hydrothermal channelways less permeable than the unaltered rock. Except for localized and seemingly random zones of joint intersections and concentrations of joints, the small amounts of grout pumped into holes that penetrate the foundation at least $100 \mathrm{ft}(33 \mathrm{~m})$ support the general perception that the foundation rock has a low permeability or seepage rate. This characteristic is confirmed by the extremely low seepage rates observed in the deep part of the excavation into the buried river channel. If any throughgoing flow channels still exist, access to them by impounded waters will be effectively reduced by the grout curtains, blankets, and keels. 


\section{EARTHQUAKE POTENTIAL AND EARTHQUAKE DESIGN CRITERIA}

\section{EARTHQUAKE POTENTIAL}

Assessments of the potential for earthquakes that may cause damage to the Jordanelle Dam, either by surface rupturing or by ground motion, are based largely on records of modern seismicity and on estimates of prehistoric seismicity. Information on the timing and recurrence of past earthquakes has been gleaned from careful studies of prehistoric faulting in the region (paleoseismology), and by making estimates of the magnitudes of past earthquakes using empirical relations established from modern surface-rupturing earthquakes on similar faults in extensional regimes of the Western United States. Using seismotectonic information from the Jordanelle damsite (Sullivan and others, 1988b) and from the adjacent region (Sullivan, 1988a), the USBR estimated the maximum magnitude of earthquakes at three different distances that may affect the Jordanelle damsite in the foreseeable future. Rather than use probability estimates, as is commonly done in hazards analyses, their approach has been to consider each of these model earthquakes as credible in their estimates of ground motion.

\section{Maximum credible earthquake}

The USBR chose to model ground motion at the Jordanelle damsite on the basis of three different maximum credible earthquake (MCE) scenarios. These scenarios involve (1) a very large-magnitude earthquake on the Wasatch fault zone, which represents a distant source; (2) a large-magnitude earthquake on an intermediate-distance source (the Round Valley faults), and (3) a lesser, but still large, magnitude earthquake on a local source (beneath the dam). On the basis of what is known about the seismotectonics of the region (Sullivan and others, 1988a, 1988b; Machette and others, 1991), these scenarios are both realistic and appropriate.

A very large-magnitude earthquake on the Wasatch fault zone is considered to be potentially of magnitude 7.5, and recent paleoseismic investigations by Machette and others (1991) confirm this estimate as geologically reasonable. Prehistoric ruptures on segments of the Wasatch fault are 25 to $44 \mathrm{mi}(40$ to $70 \mathrm{~km}$ ) long and commonly had 7-10 ft (2-3 m) to a maximum of $15 \mathrm{ft}(4.5 \mathrm{~m})$ of displacement; these ruptures probably are associated with earthquakes that had moment-magnitudes $\left(\mathrm{M}_{\mathrm{W}}\right)$ of 7.1-7.4 (Machette and others, 1991). These values are similar to Walter Arabasz's independent MCE estimate of surface-wave magnitude $\left(\mathrm{M}_{\mathrm{S}}\right)$ 7.5-7.7 (cited in Peck and others, 1990) for the Wasatch fault zone. None of the basic parameters that the USBR used in their assessment of MCE for the Wasatch fault zone have been modified by more recent investigations (Machette and others, 1991). 
The second scenario-a surface-rupturing earthquake of magnitude (Ms 6.5-6.75) from an intermediate distance source, such as the Round Valley faults—is entirely credible for the Jordanelle damsite. Empirical relations from historical faulting in the Basin and Range province and Intermountain Seismic Belt (see review in Machette and others, 1991) suggest that surface-rupturing faults in the vicinity of the damsite that could generate an earthquake of this size would form scarps that are as much as 6-12 $\mathrm{mi} \mathrm{(10-20)} \mathrm{km}$ in length and perhaps 3-7 $\mathrm{ft}(1-2 \mathrm{~m})$ high. The Panel feels assured that the USBR seismotectonic investigations (Sullivan 1988a, 1988b) would have detected such scarps in the vicinity of the Jordanelle damsite if they had formed in the late Quaternary (less than 130,000 years ago). Thus, modeling based on recurrence of movement on the Round Valley faults (or an equally distant and capable fault) is reasonable, both geologically and seismologically.

The third scenario-a lesser, but still large-magnitude $\left(\mathrm{M}_{\mathrm{L}}\right.$ 6.0-6.5) earthquake on a local source (beneath the dam)_provides an appropriately conservative and important case for an "unknown" earthquake"; that is, one that might not occur on a fault that was mapped at the surface. Much of the seismicity in Utah occurs in a belt that includes valleys within the Wasatch Range, well east of the more prominent Wasatch fault zone. Arabasz and others (1987) have been unable to link these earthquakes with known surface faults, although several models exist to explain the occurrence of earthquakes in this belt. The USBR's estimate of maximum earthquake magnitude (MS6.5) for the Bald Mountain fault is based on empirical relations between rupture length and surface displacement on historical faults in the Western United States. Therefore, on the basis of the proximity of the Bald Mountain fault (see previous discussion of "Active faults") and historic patterns of seismicity, the Panel believes that consideration of a local, randomly located, $\left(\mathrm{M}_{\mathrm{L}} \leq 6.5\right)$ earthquake is prudent. 


\section{EARTHQUAKE DESIGN CRITERIA}

Evaluating the safety of Jordanelle Dam with respect to earthquake ground shaking involves three steps: (1) identifying the earthquakes that would produce the most severe ground motion that might occur at the damsite, (2) describing the ground motion from such earthquakes, and (3) calculating the effects of the ground motion on the dam. Design earthquakes and anticipated ground motion

The USBR selected two different earthquakes for evaluating the design of the dam: a magnitude 7.5 earthquake on the Wasatch fault at a closest distance of $19 \mathrm{mi}(30 \mathrm{~km})$ and a magnitude $6.0-6.5$ earthquake beneath the damsite (Sullivan and others, 1988b). A magnitude 6.5-6.75 earthquake at an intermediate distance (such as Round Valley, $12 \mathrm{mi}(20 \mathrm{~km})$ away) was correctly judged to produce the least ground motion at Jordanelle damsite. Thus, it is not considered in the following discussion. We consider magnitude 6.5 appropriate for the local earthquake and magnitude 7.5 appropriate for the earthquake on the Wasatch fault. To represent the ground motion from these design earthquakes, the USBR used three records of simulated ground motion (Wilson, 1989). In judging the appropriateness of the records, we will look at the peak acceleration, the peak velocity, and the duration. For earthfill dams that are the size of the Jordanelle Dam $(300 \mathrm{ft}(93 \mathrm{~m})$ high), peak velocity is better than peak acceleration as a measure of the effect of ground motion. For a given peak acceleration and velocity, the damaging effect of ground motion tends to increase with increasing duration.

The first of the three simulated ground-motion records was obtained from the late H.B. Seed of the University of California, Berkeley (Wilson, 1989); this record was scaled by multiplying all of the acceleration values by a constant to obtain a peak acceleration of $0.67 \mathrm{~g}$. The peak velocity of the scaled record is $30 \mathrm{in} / \mathrm{s}(76 \mathrm{~cm} / \mathrm{s})$; it was chosen to represent the local earthquake. By way of comparison, equations given by Joyner and Boore (1988) yield median values of $0.42 \mathrm{~g}$ and $21 \mathrm{in} / \mathrm{s}(53 \mathrm{~cm} / \mathrm{s})$ and 84 th percentile values of $0.79 \mathrm{~g}$ and $44 \mathrm{in} / \mathrm{s}(113 \mathrm{~cm} / \mathrm{s})$ for a magnitude 6.5 earthquake at zero distance. The peak acceleration of the first record corresponds to the 76th percentile, according to the Joyner-Boore equations, and the peak velocity corresponds to the 68 th percentile. Some might argue that larger motions with smaller probabilities of being exceeded should be used in view of the extreme consequences of failure of the dam. That argument can be rejected, however, because the magnitude 6.5 earthquake at zero distance is itself a low-probability event, and it is not necessary to also consider a low-probability ground motion. Equations given by Dobry and others (1978) yield a median duration of $9 \mathrm{~s}$ and an 84 th percentile value of 
$12 \mathrm{~s}$ for a magnitude 6.5 earthquake at a rock site (such as Jordanelle). We have not computed the duration of the USBR's first record according to the Dobry and others' definition (which the Panel considers the best to use), but from our visual examination of the record, we are confident it exceeds $12 \mathrm{~s}$. In summary, the Panel considers the first record an appropriate representation of the magnitude 6.5 earthquake at the damsite.

The second simulated ground-motion record was generated synthetically to represent the local earthquaice. It has a peak acceleration of $0.55 \mathrm{~g}$ and a peak velocity of $14 \mathrm{in} / \mathrm{s}(35 \mathrm{~cm} / \mathrm{s})$. The peak acceleration corresponds to the 66 th percentile for a magnitude 6.5 earthquake at zero distance, according to the Joyner and Boore (1988) equations, but the peak velocity corresponds only to the 29 th percentile, significantly below the median. Examination of the record indicates that the duration is approximately equal to the median value of $9 \mathrm{~s}$ given by the equations of Dobry and others (1978). The Panel does not consider the second record an adequate representation of the magnitude 6.5 local earthquake because of the small value of peak velocity, but this deficency is compensated by the previously described record.

The third simulated ground-motion record was obtained by scaling a simulated record developed by H.B. Seed and I.M. Idriss at the University of California, Berkeley. The record appears to be the one described by Seed and Idriss (1969). The record was scaled to a peak acceleration of $0.29 \mathrm{~g}$ to represent the magnitude 7.5 earthquake on the Wasatch fault at a distance of $30 \mathrm{~km}$. The peak acceleration corresponds to the 82 nd percentile, according to the Joyner and Boore (1988) equations. The peak velocity of the scaled record is not given, but judging from the velocity-response spectrum, the motion is sufficiently strong in the period range corresponding to structures like the Jordanelle Dam. (The velocity-response spectrum shown by Wilson (1989) is incorrectly labeled; the vertical scale should be feet per second, not inches per second.) The entire record is not shown in the documents that we reviewed, but judging from the $36 \mathrm{~s}$ of record shown and referring to Seed and Idriss (1969), we conclude that the duration exceeds the 84th percentile value of $33 \mathrm{~s}$ given by Dobry and others (1978) for a magniude 7.5 earthquake at a rock site. The Panel considers the third simulated ground-motion record an appropriate representation of the magnitude 7.5 earthquake on the Wasatch fault $19 \mathrm{mi}(30 \mathrm{~km})$ away.

\section{Effects of ground motion on dam}

To determine the effect these three simulated ground-motion records would have on the dam, the USBR used a variation of the widely accepted Newmark (1965) method. Evaluation of the USBR's calculations is an engineering 
matter that the Panel is not prepared or qualified to make. We will, however, describe the results briefly.

Preliminary calculations by Wilson (1989) indicated that deformations were much larger for the first record than for the other two records, and that the maximum vertical deformation for the first record was $4.6 \mathrm{ft}(1.4 \mathrm{~m})$, only about $1 / 4$ of the freeboard designed for the dam $(18 \mathrm{ft}, 5.5 \mathrm{~m})$. Later, when test data on the compacted earthfill became available, the calculations were repeated using the first record and strength values that the USBR believes are conservative in light of the newer data (McLean, 1990). The recalculated maximum vertical deformation was $13 \mathrm{ft}$ (4 $\mathrm{m})$, larger than in the preliminary calculations by a factor of three, but still less than the design freeboard of $18 \mathrm{ft}$ (5.5 $\mathrm{m}$ ) The lowest factor of safety was 1.24 , indicating that the embankment would retain sufficient strength to remain stable.

In the preliminary calculations, it was shown that the vertical deformations were much larger for the adopted downstream slope of $1.5: 1$ than for slopes of $1.75: 1$ or $2: 1$. The 1.5:1 slope is steeper than that for "most comparable dams of similar material," which have slopes in the range of 1.75:1 to 2.25:1 (Peck and others, 1988). The 1988 Consulting Group, however, commended the designers "for breaking from an ultraconservative tradition" (Peck and others, 1988).

\section{RESERVOIR-INDUCED SEISMICITY}

Impoundment of reservoirs may actually cause earthquakes either because of weight of the reservoir water or the increase in pore-water pressure in the underlying materials due to the presence of the reservoir (Simpson, 1986). Jordanelle Dam will create a reservoir that will be $230-282 \mathrm{ft}(70-86 \mathrm{~m})$ deep when filled to active conservation capacity, and to as much as $290-341 \mathrm{ft}(88-104 \mathrm{~m})$ at maximum capacity (spillway level). Evaluation of dam safety must include consideration of the possibility of reservoir-induced seismicity. Lack of evidence for reservoir-induced seismicity at existing USBR reservoirs in the valleys within the Wasatch Range of north-central Utah (Sullivan and others, 1988a) means little because they are all shallower than the pianned Jordanelle Reservoir and the probability of reservoir-induced seismicity is sensitively dependent on depth.

The USBR (Sullivan and others, 1988b) estimates the probability of reservoir-induced seismicity at Jordanelle as 6-7 percent, based on the methods of Baecher and Keeney (1982), which rely on a number of reservoir characteristics. This estimate is similar to the 6-percent estimate given by Stuart-Alexander and Mark (1976) for reservoirs between $295 \mathrm{ft}$ and $395 \mathrm{ft}$ (90 m and $120 \mathrm{~m}$ ) in depth. Probabilities of this magnitude are not negligible when considering a 
structure such as a dam whose failure may have extremely serious consequences. The ground-shaking hazard from reservoir-induced earthquakes needs no additional consideration, because the natural design earthquakes include a magnitude 6.5 earthquake directly under the damsite. The largest earthquake in the world that is thought to be reservoir-induced is the 1967 magnitude 6.5 earthquake at Koyna Dam in India. What needs consideration in connection with reservoir-induced seismicity is the possibility of a fault in the dam foundation which has such a low rate of natural activity that it goes unrecognized, but which will move when the reservoir is filled. To understand this possibility, one must consider the analysis of induced seismicity by Simpson (1986). He showed that a fault with an arbitrarily large return period for natural activity (recurrence interval) will have a probability of induced rupture that is equal to the stress change due to the reservoir divided by the stress drop of the earthquake. The stress change for a $328-\mathrm{ft}(100-\mathrm{m})$ reservoir is $10 \mathrm{bars}$, and the stress drop in earthquakes, though poorly determined, is generally in the range of 10 to 100 bars, giving a probability on the order of 10 percent, independent of the rate of natural earthquake activity.

There is no reason to consider that surface rupure will be unlikely in an induced earthquake. Of the seven major reservoir-induced earthquakes listed by Simpson (1986), three have reported surface rupture: Koyna, India, 1967 $(M=6.5)$; Hsinfengkiang, China, 1962 ( $M-6.1)$; and Oroville, Califomia, $1975(M=5.9)$. The reservoir depths at Koyna (328 ft (100 m)) and Hsinfengkiang (262 ft (80 m)) (Woodward-Clyde Consultants, 1977) are about the same as that planned for Jordanelle. The Koyna earthquake was accompanied by one $\mathrm{ft}(30 \mathrm{~cm})$ of left-lateral surface rupture on a Holocene fault (Woodward-Clyde Consultants, 1977; Lloyd S. Cluff, personal commun., 1991) and the Hsingfengkiang earthquake was accompanied by 9 in $(19 \mathrm{~cm})$ of surface rupture (Woodward-Clyde Consultants, 1977). The reservoir depth at Oroville is about $650 \mathrm{ft}(200 \mathrm{~m})$, and the Oroville earthquake, whose status as a reservoir-induced earthquake is less clear than the other two, was accompanied by surface rupture with a maximum slip of 2.2 in (5.5 cm) (Clark and others, 1976; Bell and Nur, 1978). The USBR has allowed for as much as 6 in $(15 \mathrm{~cm})$ of fault rupture in the foundation. The possibility of reservoir-induced faulting might lead one to consider displacements as large as 20 in (50 cm). Ralph B. Peck (member of the USBR 1990 Consulting Group), however, assured us (personal commun., 1991) that the earthfill dam as designed will tolerate 20 in $(50 \mathrm{~cm})$ of displacement, if faulting did occur. 
The Panel understands that the USBR plans to monitor seismicity during filling of the reservoir. The Panel endorses these plans, but wam that monitoring and staged filling cannot be relied upon to protect against large reservoir-induced earthquakes. "At Oroville and Koyna, the water levels had been close to the maximum for 4 to 6 years prior to the time of the large earthquakes." (Simpson, 1986).

\section{CONCLUSIONS-EARTHQUAKE POTENTIAL AND DESIGN CRITERIA}

USBR seismotectonic investigations suggest three different scenarios for earthquakes that may affect the Jordanelle damsite. Although these earthquakes are unlikely (they have inferred repeat times of 2,000 to more than 50,000 years), the USBR used a conservative approach in their design, which allows the occurrence of these earthquakes during the life-span of the dam. A conservative approach is appropriate for a structure such as a dam whose failure may have serious consequences. Seismotectonic data obtained since 1988 do not alter USBR estimates of the maximum credible earthquake that could affect the damsite.

The USBR used two of the design earthquakes to represent the earthquake potential of the damsite, a magnitude 7.5 earthquake on the Wasatch fault $19 \mathrm{mi}(30) \mathrm{km}$ distant and a magnitude 6.0-6.5 earthquake in the immediate vicinity of the damsite. We consider magnitude 6.5 appropriate for the local earthquake and magnitude 7.5 appropriate for the Wastach fault. To represent the ground motion from these design earthquakes, the USBR used three records of simulated motions. The first two records were intended to represent the local earthquake and the third to represent a magnitude 7.5 on the Wasatch fault at a distance of $19 \mathrm{mi}(30 \mathrm{~km})$. The Panel is not entirely satisfied with the second record, but we believe that the first and third records taken together provide an appropriate basis for design. The USBR used these records to calculate the effects of the two earthquakes on the dam. Evaluation of the calculations is a matter of engineering judgment that the Panel is not prepared to undertake, but we note the the calculations, based on assumed strength values that the USBR considers conservative, indicate that the dam design is adequate.

Evaluation of the earthquake safety of the dam must include consideration of the potential of earthquakes of magnitude up to 6.5 that are induced by the impoundment of water in the reservoir. The ground-shaking hazard from such earthquakes does not need special consideration because there is no reason to expect that the shaking would exceed that represented by the design ground-motion records described above. However, an argument can be made that fault rupture in an induced earthquake might exceed the 6-in $(15-\mathrm{cm})$ upper limit given by the USBR. The most 
recent Consulting Group has assured us that the dam, as designed, can safely accommodate rupture displacements as large as 20 in $(50 \mathrm{~cm})$, which, in our opinion, are as large as need be considered.

\section{OVERALL CONCLUSIONS}

The U.S. Geological Survey Panel has found no safety concerns relating to geologic or seismologic issues that remain to be resolved at the Jordanelle damsite. The near-complete exposure of the foundation rock, an effort which is unprecedented for a damsite such as Jordanelle, has provided an excellent base for the USBR comprehensive and detailed mapping of the foundation exposures and has allowed them to integrate extensive subsurface drill-hole data with surface geology. We have reviewed the USBR investigations at the Jordanelle damsite with reference to perported hazards from active faulting, leaky and crumbly foundation rock, landsliding, embankment failure due to ground shaking from earthquakes, and induced seismicity —each of which are important considerations in the design and construction of a critical facility. The Panel is satisfied that the USBR has fully demonstrated that these issues do not constitute a bonafide threat to the dam. 


\section{REFERENCES CITED}

Arabasz, W J., Pechmann, J.C., and Brown, E.D., 1987, Observational seismology and the evolution of earthquake hazards and risk in the Wasatch Front area, Utah, in Gori, P.A. and Hays, W.W., eds., Assessment of Regional Earthquake Hazards and Risk along the Wasatch Front, Utah: U.S. Geological Survey Open-File Report 87-585-I, p. D1-D58.

Baecher, G.B., and Keeney, R.L., 1982, Statistical examination of reservoir-induced seismicity: Seismological Society of American Bulletin, v. 72, p. 553-569.

Bell, M.L., and Nur, A., 1978, Strength changes due to reservoir-induced pore pressure and stresses and application to Lake Oroville: Journal of Geophysical Research, v. 83, p. 4469-4483.

Best, M.G., 1986, Review of the geology of the middle east abutment of the Jordanelle, Utah, Damsite, in Jordanelle Dam-Technical Summary Document: U.S. Bureau of Reclamation, Bonneville Construction Office, Provo, Utah, v. 1, 11 p. (September, 1986).

Bridges, Robert, 1984, Geology report, Jordanelle Reservoir, in Geologic Design Data Report for Jordanelle damsite and reservoir, Central Utah Project, Utah: U.S. Bureau of Reclamation, Bonneville Construction Office, Provo, Utah, v. VII (Consultant's Reports), 40 p., 8 figures (April 1985).

Bromfield, C.S., Baker, A.A., and Crittenden, M.D., Jr., 1970, Geologic map of the Heber quadrangle, Wasatch and Summit Counties, Utah: U.S. Geological Survey Geologic Quadrangle Map GQ-864, scale 1:24,000

Clark, M.M., Sharp, R.V., Castle, R.O., and Harsh, P.W., 1976, Surface faulting near Lake Oroville, California in August 1975: Seismological Society of America Bulletin, v. 66, p. 1101-1110.

Dobry, R., Idriss, I.M., and Ng, E., 1978, Duration characteristics of horizontal components of strong-motion earthquake records: Seismological Society of America Bulletin, v. 68, p. 1487-1520.

Fox, R.C. (Practical Geophysics Inc.), 1984, Geophysical survey, Jordanelle damsite, 1984 in Geologic Design Data Report for Jordanelle damsite and reservoir, Central Utah Project, Utah: U.S. Bureau of Reciamation, Bonneville Construction Office, Provo, Utah, v. VII (Consultant's Reports), 6 p., 5 plates, 11 figures (April 1985).

Goter, Susan, compiler, 1991, Earthquakes in Utah, 1884-1989: U.S. Geological Survey Open-File Report 91-128, scale 1: 500,000 . 
Hecker, Suzanne, in preparation (1991), [Map of] Quatemary tectonics of Utah with emphasis on seismic-source characterization: Utah Geological Survey Bulletin (or Special Series), scale 1:500,000.

Joyner, W.B., and Boore, D.M., 1988, Measurement, characterization and prediction of strong ground motion, in Earthquake Engineering and Soil Dynamics II, Proceedings of the American Society of Civil Engineering Geotechnical Engineering Division Specialty Conference, June 27-30, 1988, Park City, Utah, p. 43-102. Machette, M.N., Personius, S.F., Neison, A.R., Schwartz, D.P., and Lund, W.R., 1991, The Wasatch fault zone, Utah-Segmentation and history of Holocene earthquakes: Journal of Structural Geology, v. 13, no. 2, p. 137-149.

McLean, F.G., 1990, Leter to Dr. Ralph Peck, dated February 12, 1990: U.S. Bureau of Reclamation, Center for Engineering Research, Denver, Colorado, 5 p. (plus figures).

Merriam, R. H., 1980, Preliminary geologic mapping at Jordanelle Damsite, in Geologic Design Data Report for Jordanelle damsite and reservoir, Central Utah Project, Utah: U.S. Bureau of Reclamation, Bonneville Construction Office, Provo, Utah, v. VII (Consultants Reports), 14 p., 9 sheets at 1:2,400 scale (July, 1980).

Newmark, N.M., 1965, Effects of earthquakes on dams and embankments: Geotechnique, v. 15, p. 139-160.

Peck, R.B., Arabasz, W J., and McCusker, T., 1988, Jordanelle Dam: Joint report of architect-engineer consulting group to U.S. Bureau of Reclamation, Engineering and Research Center, Denver, Colorado, May 30, 1988.

Seed, H.B., and Idriss, I.M., 1969, Rock motion accelerograms for high magnitude earthquakes: Earthquake Engineering Research Center, University of California, Berkeley, Report No. EERC 69-7, 8 p.

Simpson, D.W., 1976, Seismicity changes associated with reservoir loading: Engineering Geology, v. 10, p. 123150.

1986, Triggered earthquakes: Annual Review of Earth and Planetary Sciences, v. 14, p. 21-41.

Stuart-Alexander, D.E., and Mark, R.K., 1976, Impoundment-induced seismicity associated with large reservoirs: U.S. Geological Survey Open-File Report 76-770.

Sullivan, J.T., Nelson, A.R., LaForge, R.C., Wood, C.K., and Hansen, R.A., 1988a, Central Utah regional seismotectonic study for USBR dams in the Wasatch Mountains: Denver, Colorado, U.S. Bureau of Reclamation Seismotectonic Report 88-5, 269 p. 
Sullivan, J.T., Martin, R.A., Foley, L.L., Wood, C.K., and LaForge, R.C., 1988b, Seismotectonic study for Jordanelle Dam, Bonneville Unit, Central Utah Project, Utah: Denver, Colorado, U.S. Bureau of Reclamation Seismotectonic Report 88-6, 76 p. (plus appendices).

U.S. Bureau of Reclamation, 1985, Geologic design data report for Jordanelle damsite and reservoir, Central Utah Project, Utah: U.S. Bureau of Reclamation, Bonneville Construction Office, Provo, Utah, v. VII (Consultants Reports), April 1985.

U.S. Bureau of Reclamation, 1986, Jordanelle Dam-Technical summary document: U.S. Bureau of Reclamation, Bonneville Construction Office, Provo, Utah, four volumes (September 1986).

Wilson, J.A., 1989, Seismically induced embankment deformations, Jordanelle Dam, Central Utah Project, Utah: U.S. Bureau of Reclamation, Geotechnical Engineering and Geology Division, Technical Memorandum No. JD-3620-8, 8 p. (plus references, tables, and figures).

Woodward-Clyde Consultants, 1977, Reservoir-induced seismicity (v. 6), in Earthquake evaluation studies of the Auburn Dam area [California]: Woodward-Clyde Consultants report to U.S. Bureau of Reclamation, Office of Design and Construction, Denver, Colorado, July 1977, v. 6, 124 p., appendices and references.

\section{DOCUMENTS REVIEWED}

The majority of pre-1985 documents relate to initial stages of construction at Jordanelle, and many of these have been superseded by later documents. The majority of our investigation centers around current issues at Jordanelle, thus the Panel has largely restricted our investigation to these matters and pertinent documents. In addition to the list of cited references, we reviewed the following list of major USBR technical documents and other unpublished materials that were supplied by third party-scientists, such as Leon Hansen.

Arabasz, W.J., 1990, Brief letter report of review and one-day site visit, Jordanelle Dam, Bonneville Unit, Central Utah Project: U.S. Bureau of Reclamation, Engineering and Research Center, Denver, Colorado (May 12, 1990).

Arabasz, W.J., Jahns, R.H., and Peck, R.B., 1983, Review and analysis of geologic, seismotectonic, and design data for the proposed Jordanelle Dam, Bonneville Unit, Central Utah Project: Joint report to U.S. Bureau of Reclamation, Engineering and Research Center, Denver, Colorado (February, 1983). 
Campbell, D.D., 1990, Summary report, Jordanelle Dam, Bonneville Unit, Central Utah Project: U.S. Bureau of Reclamation, Engineering and Research Center, Denver, Colorado (August 19,1990).

Peck, R.B., 1990, Brief letter report of review and one-day site visit, Jordanelle Dam, Bonneville Unit, Central Utah Project: U.S. Bureau of Reclamation, Engineering and Research Center, Denver, Colorado (November 7 , 1989).

Peck, R.B., Arabasz, W J., Tarbox, G.S., and Campbell, 1986, Joint report of Architect-Engineer Consulting Group, Jordanelle Dam, Bonneville Unit, Central Utah Project: U.S. Bureau of Reclamation, Engineering and Research Center, Denver, Colorado (December 3, 1986).

Peck, R.B., Arabasz, W J., McCusker, T., 1988, Joint report of Architect-Engineer Consulting Group, Jordanelle Dam, Bonneville Unit, Central Utah Project: U.S. Bureau of Reclamation, Engineering and Research Center, Denver, Colorado (May 30, 1988).

Sullivan, J.T., Nelson, A.R., LaForge, R.C., Wood, C.K., and Hansen, R.A., 1988a, Central Utah regional seismotectonic study for USBR dams in the Wasatch Mountains: Denver, Colorado, U.S. Bureau of Reclamation Seismotectonic Report 88-5, 269 p.

Sullivan, J.T., Martin, R.A., Foley, L.L., Wood, C.K., and LaForge, R.C., 1988b, Seismotectonic study for Jordanelle Dam, Bonneville Unit, Central Utah Project, Utah: Denver, Colorado, U.S. Bureau of Reclamation Seismotectonic Report 88-6, 76 p.

U.S. Bureau of Reclamation, 1985, Geologic design data report for Jordanelle damsite and reservoir, Central Utah Project, Utah: U.S. Bureau of Reclamation, Bonneville Construction Office, Provo, Utah, v. VII (Consultant's Reports), April 1985.

U.S. Bureau of Reclamation, 1986, Jordanelle Dam-Technical summary document: U.S. Bureau of Reclamation, Bonneville Construction Office, Provo, Utah, 4 volumes (September 1986).

U.S. Bureau of Reclamation, 1987, Geology report for results of Jordanelle Dam angle hole drilling program proposed by the 1986 Consulting Group: U.S. Bureau of Reclamation, Bonneville Construction Office, Provo, Utah, 1 volume (August, 1987).

U.S. Bureau of Reclamation, 1991, Maps of foundation geology (ongoing program): U.S. Bureau of Reclamation, Bonneville Construction Office, Provo, Utah, 3 sheets (JORD 150, 250, and 350), scale 1:600. 
Wilson, J.A., 1989, Seismically induced embankment deformations, Jordanelle Dam, Central Utah Project, Utah: U.S. Bureau of Reclamation Technical Memorandum No. JD-3620, 9 p., 3 tables, 18 figures (includes correspondence and enclosures of 1/26/90 from F.G. McLean to R.B. Peck). 